DANIEL LUPORINI DE FARIA

\title{
O PROBLEMA DA RELAÇÃO MENTE-CORPO E A CONSCIÊNCIA COMO SUA MANIFESTAÇÃO
}

Dissertação apresentada ao Programa de Pós-graduação em Filosofia, da Faculdade de Filosofia e Ciências, da Universidade Estadual Paulista - UNESP - Campus de Marília, para obtenção do título de Mestre em Filosofia. Área de concentração: Filosofia da mente, epistemologia e lógica.

Orientadora: Profa. Dra. Maria Eunice Quilici Gonzalez.

Marília 


\section{COMPONENTES DA BANCA EXAMINADORA}

Profa. Dra. Maria Eunice Quilici Gonzalez (orientadora)

Departamento de filosofia

FFC - UNESP - Marília

Profa. Dra Mariana Claudia Broens

Departamento de filosofia

FFC - UNESP

Prof. Dr. Osvaldo Frota Pessoa Jr.

Departamento de filosofia

FFlCH - USP

\section{Suplentes}

Profa. Dra. Carmen Beatriz Millidoni

Departamento de filosofia

FFC - UNESP - Marília

Profa. Dra. Ítala M. Loffredo D' Ottaviano Centro de lógica, epistemologia e história da ciência, departamento de filosofia, IFCH UNICAMP 
Para Nice e Mariana; mulheres que com muito carinho, dedicação e sobretudo, paciência, em muito contribuíram na minha formação, permitindo a realização deste trabalho. 


\section{Agradecimentos}

Agradeço a meu pai, minha mãe, irmã e cachorros pelo carinho e atenção dispensada nos momentos alegres e tristes. Agradeço igualmente aos amigos Maira e Caio (e família), Diadema, Zé, Mano, Ramon, Renato, Anderson, Fernandão, Tocha, Mala, Cae, Lú, Alex, Ximbica, Milton, Sinomar, etc. (meus amigos sabem quem são), pelo apoio e estímulo intelectual resultante das frutíferas conversas sobre futebol, política, o lugar da mente no cosmo, consciência, dentre outras instigantes questões. Agradeço também à Edna do departamento de filosofia pela paciência e competência em lidar com questões técnicas que permearam a confecção deste e de tantos outros trabalhos. Por último, um agradecimento especial à Bel Loureiro, Mariana e Nice; mulheres responsáveis por minha formação acadêmica, e, em grande medida, minha formação para a vida. 
A consciência de si mesma era, pois, uma simples função da matéria organizada em prol da vida, e numa fase mais elevada dirigia-se a função contra o seu próprio portador, convertia-se no desejo de pesquisar e explicar o fenômeno ao qual deu origem, na tendência esperançosa e desesperada da vida para se conhecer a si própria. (Mann, T. A montanha mágica, 1980, p. 308). 


\section{RESUMO}

A presente dissertação analisa a relação mente-corpo em suas perspectivas ontológica e epistemológica. O foco da análise se situa no tratamento de questões associadas às equivalentes noções de sensação, consciência, experiência consciente ou simplesmente experiência. Assim, partindo da concepção de que a relação mente-corpo se coloca enquanto problema filosófico, sobretudo a partir do contexto da filosofia cartesiana, investiga-se o modo como tal problema é abordado sob as perspectivas materialista e funcionalista desenvolvidas na filosofia da mente. As abordagens materialistas escolhidas seriam a teoria da identidade mente-cérebro, tal como Smart (1970) a propõe, e o eliminativismo formulado por P. M. Churchland (2004). No que diz respeito à abordagem funcionalista da mente, ênfase é conferida à possibilidade de se definir funcionalmente os aspectos qualitativos da experiência, especialmente, no que diz respeito à perspectiva funcionalista delineada por Shoemaker (1980). Após tais análises, indica-se um desestimulante ceticismo, tendo em vista a opinião de que tanto as abordagens materialistas investigadas quanto a perspectiva funcionalista escolhida falham, a rigor, em dirimir o problema mente-corpo, bem como explicar a experiência consciente. Porém, para evitar um ceticismo em relação a tais problemas, propõe-se, ao final do trabalho, o resgate dos estudos de Ryle, em que a relação mente-corpo e a questão epistemológica da experiência consciente podem ser mais bem compreendidas tendo em vista uma perspectiva que denominamos de relacional. De acordo com essa perspectiva e a mente é concebida não mais como coisa (res), localizada num recipiente de acesso privilegiado, mas como uma propriedade disposicional, de múltiplas vias, expressa no comportamento e na história vivida de cada sistema.

Palavras-chave: Mente, Corpo,. Sensação,. Consciência, Estado Disposicional, Qualia 


\begin{abstract}
This dissertation analyses the mind-body relation in its ontological and epistemological perspectives. It's main focus of analysis is the treatment of questions associated to equivalent notions of sensation, consciousness, conscientious experience, or simply experience. Thus, starting with the supposition that the mind-body relation is a philosophical problem, mainly in the context of the Cartesian philosophy, it is investigated the way such a problem is treated under the materialist and functionalist perspectives in the philosophy of mind. The materialist approach investigated is based on the mind-brain identity theory proposed by Smart's (1970), and on versions of eliminativism formulated by Churchland (2004). In relation to the functionalist approach, it is investigated the possibility of defining functionally the qualitative aspects of experience, specially from the perspective delineated by Shoemaker (1980). A certain scepticism is indicated concerning the materialist and the functionalist perspectives investigated, it is argued that strictly speaking, they fail in their attempts to solve the mind-body problem and to explain conscientious experiences. However, in order to avoid scepticism in relation to these problems, it is suggested that the mind-body problem and the epistemological nature of conscientious experience can be better understood Ryle relational perspective. According to this perspective, the mind is conceived not as a thing (res), situated in a recipient with privileged introspective access, but as a disposicional property of the multiple vias expressed in behaviour and in the lived history of each system.
\end{abstract}

Key-words: Mind, Body, Sensation, Consciousness, disposicional States Qualia. 


\section{SUMÁRIO}

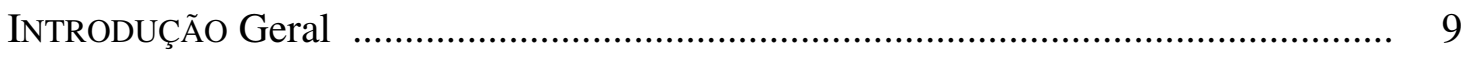

CAPÍTULO 1 - O PROBLEMA MENTE-CORPO E A CONSCIÊNCIA COMO SUA EXPRESSÃO . 13

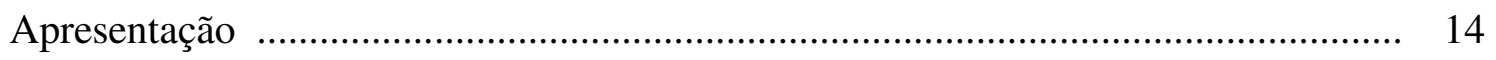

1.1 O problema mente-corpo na concepção cartesiana e o bom senso como marca 16 distintiva do humano

1.2 Livre arbítrio e determinismo: o lugar do humano e da consciência .................... 27

1.3 A formulação contemporânea do problema mente-corpo ……………………..... 36

CAPÍTULO 2 - ABORDAGENS MATERIALISTAS DA MENTE: TEORIAS DA IDENTIDADE E 45 ELIMINATIVISMO

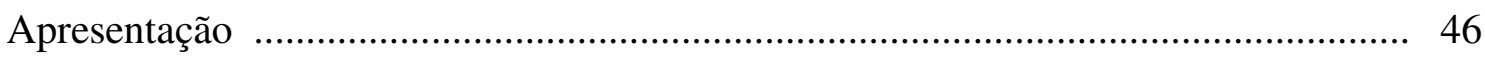

2.1 Propostas materialistas de entendimento da relação mente-corpo ......................... 47

2.2 As limitações do materialismo ....................................................................... 61

Capítulo 3 - A PROPOSTA FUNCIONALISTA DA MENTE ………………........................ 77

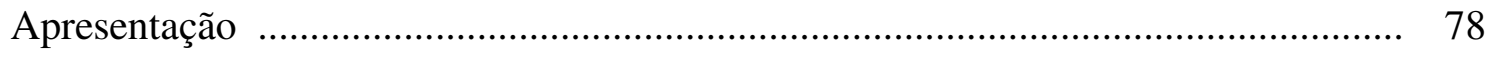

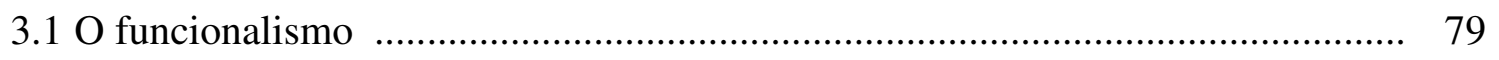

3.2 Mente, linguagem e perspectivas futuras ………………………………......... 93

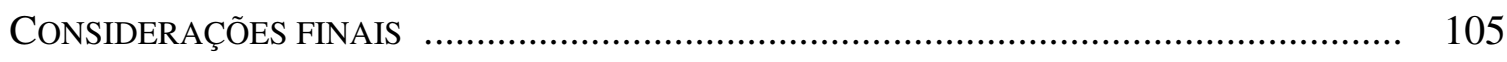

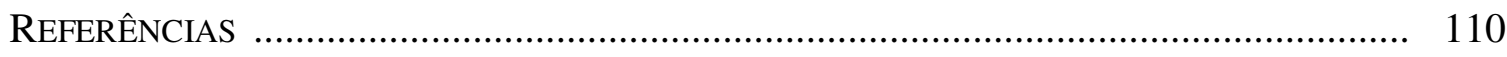




\section{Introdução geral}

Desde os primórdios da filosofia, a questão acerca de como se dá a relação entre a mente ou psique (ou o elemento simbólico talvez seja o termo mais adequado) com o corpo ou matéria, tem gerado enorme perplexidade. Como discutiremos no trabalho que se segue, entendemos (o que é bem questionável) que o problema da relação mente-corpo se coloca de maneira "clara e distinta" sobretudo, a partir dos escritos de Descartes.

Mas independentemente de algumas posições problemáticas expressas no arcabouço teórico-conceitual cartesiano, em que a relação mente-corpo se coloca como um problema aparentemente "intratável”, não devemos esquecer que, no plano clínico ou "pragmático", a teoria dos humores, inicialmente desenvolvida por Hipócrates e aperfeiçoada por Galeno, era capaz de lidar, ou melhor, estabelecer associações coerentes (e porque não eficazes clinicamente?) entre os males do corpo e da mente ${ }^{1}$. Porém, talvez não seja exagero dizer que num plano mais abstrato ou filosófico, questões relativas ao estatuto da mente e da "realidade palpável", e também questões relativas à interação entre tais âmbitos, já deram lugar a reflexões que incomodavam alguns pensadores da antiguidade grega.

Aristóteles (1967), por exemplo, se indaga a respeito do como e porquê a mente, que é capaz de sentir, bem como perceber ou captar impressões, interage com objetos que aparentemente não apresentam tais propriedades, ou seja, que "presumivelmente" não são sensitivos ou capazes de apreender impressões (p. 854).

\footnotetext{
${ }^{1}$ Cf. Margotta, R., 1998.
} 
No contexto da psicologia, Freud no "adiado" Projeto de uma psicologia suspeitava que a principal razão da não compreensão da relação mente-corpo derivava da ins (c) ipiência ${ }^{2}$ no que tange aos conhecimentos técnicos, e, principalmente, teóricoconceituais acerca de neurofisiologia. Deste modo, a alternativa encontrada por Freud foi a de ater-se unicamente ao plano psíquico ou simbólico ${ }^{3}$.

Mesmo com o crescente avanço da neurociência, verificado sobretudo após a segunda metade do século XX, talvez seja sintomática a constatação de que ainda haja um número expressivo de psicólogos e psicanalistas, das mais diversas orientações, que se mantém fiéis (diante de "psicopatologias" de diversos matizes) aos procedimentos unicamente especulativos ou teórico conceituais; ignorando, ou melhor, expressando reticências com relação ao plano corpóreo. O mesmo pode ser dito (só que inversamente) da psiquiatria tradicional, que, ignorando as tensões afetivas e simbólicas do indivíduo, concebem a "saúde mental” em termos da harmonia eletroquímica cerebral.

O que pode ser extraído do parágrafo precedente é o tecido que compõe o pano de fundo que sustenta uma outra importante desconfiança de Freud, qual seja, a de que talvez haja uma "impermeável couraça" que impossibilita a comunhão entre os saberes relativos ao corpo e os saberes da mente. Quanto à natureza dessa (no mínimo aparente) couraça impermeável, que incomoda tanto os reducionistas quanto os entusiastas defensores das concepções interdisciplinar, em especial, da interdisciplinaridade subjacente à ciência cognitiva, podemos aventar a problemas lógico-filosóficos, epistemológicos, metafísicos, e

\footnotetext{
${ }^{2}$ Destacamos o termo insipiência, dando margem para se pensar também em insipiência (com s), no sentido de que ambos os termos talvez se apliquem às inquietações vivenciadas por Freud em boa parte de sua vida. Assim, pode-se dizer que incipiente (com c) denotaria algo que está no começo; ao passo que insipiente remeteria àquilo que se desconhece, se ignora.

${ }^{3}$ Cf. Milidoni, C. B., 2001.
} 
por que não dizer, sociais. Obviamente não pretendemos endereçar tais questões tão complexas, mas procuraremos delinear algumas delas no decorrer deste trabalho.

Dado este breve preâmbulo acerca da milenar perplexidade e dificuldade inerentes à relação mente-corpo, pretendemos $\mathrm{n}$ analisar tal relação tanto em sua dimensão ontológica quanto epistemológica. Veremos que, contemporaneamente, ao se conceber como uma das expressões da relação mente-corpo uma concepção de consciência assimilada aos aspectos qualitativos da experiência, abrem-se precedentes para a colocação de problemas de ordem ontológica e epistemológica extremamente difíceis de serem superados.

Sendo assim, apresentaremos, no primeiro capítulo, a formulação, na perspectiva cartesiana, do que se convencionou chamar de problema mente-corpo. Ademais, teceremos, com algum pormenor, uma análise sobre os elementos que julgamos centrais na metafísica cartesiana, tendo em vista a compreensão de sua singular concepção de homem: uma criatura cindida entre um corpo e uma mente, que, tendo o sentimento como um dos "modos de ser do pensamento", não pode propriamente sentir ou captar sensações sem um corpo.

Em seguida, apresentaremos, num viés contemporâneo, o problema da relação mente-corpo nas perspectivas ontológica e epistemológica, ressaltando o problema da experiência consciente como manifestação dessa problemática relação.

No segundo capítulo, apresentaremos e problematizaremos algumas teorias de orientação materialista em filosofia mente; mais especificamente, num primeiro momento, a teoria da identidade tal como Smart (1970) a propõe, e, num segundo momento, o materialismo eliminativo de P. M. Churchland. Em relação à problematização de tais 
perspectivas, avaliaremos algumas críticas dirigidas a ambas abordagens, bem como algumas réplicas por parte de seus proponentes.

No terceiro e último capítulo, analisaremos, inicialmente, a perspectiva funcionalista da mente, em especial, aquela defendida por Shoemaker (1980), segundo a qual os estados mentais, em especial, os aspectos qualitativos que acompanham a experiência consciente, podem ser funcionalmente definidos. Neste sentido, argumentaremos que mesmo que se defina numa tabela os matizes de um dado estado qualitativo, ainda assim, o problema da experiência consciente tende a permanecer tendo em vista sua própria formulação. No entanto, destacaremos que mediante acurada análise do comportamento e da linguagem, epistemologicamente, tanto a relação mente-corpo quanto a questão da experiência consciente podem ser mais bem compreendidas.

Ao final do trabalho, delinearemos algumas perspectivas futuras abertas pelo trabalho, apontando brevemente que mediante as noções de espaço informacional e duplo aspecto da informação, tal como Chalmers $(1996,1997)$ as concebe, a questão da experiência consciente talvez possa ser mais bem entendida. 
Capítulo 1 - O problema mente-corpo e a consciência como sua expressão 


\section{Apresentação}

O objetivo deste capítulo consiste em analisar, na primeira seção, o problema mente-corpo no contexto da filosofia cartesiana.

Ao esquematizarmos as características que compõem o corpo e a mente, nos debruçaremos sobre o ponto que julgamos ser essencial na metafísica cartesiana, a saber: o (s) princípio (s) que rege $(\mathrm{m})$ o funcionamento da mente; em outras palavras: a própria noção de racionalidade em Descartes. Para tanto, investigaremos o modo como esse filósofo articula em sua filosofia as noções de livre-arbítrio, moral e razão.

Na segunda seção, mediante a análise de uma das características da mente ou "um dos modos de ser" do pensamento (que é o sentimento), analisaremos a singular concepção de homem na filosofia cartesiana; entendido como o único ser no qual se daria a união da mente com o corpo, bem como o único ser racional, possuidor de consciência e capaz de introspeção. Estas duas últimas propriedades - capacidade introspectiva e racionalidade consideradas essencialmente humanas, serão também investigadas. Ao final da segunda seção, devido ao grande número de questões abordadas nas duas primeiras seções, retomaremos alguns pontos que julgamos comuns a elas, tendo em vista a sinalização do que discutiremos no decorrer do trabalho.

Finalmente, na terceira seção do presente capítulo, discutiremos o legado da filosofia cartesiana referente à concepção contemporânea da relação mente-corpo. Assim, veremos que a partir de uma perspectiva contemporânea, o "problema" mente-corpo (um modo usual hoje em dia de se referir à relação entre a mente e o corpo) é comumente formulado numa perspectiva que tende a ressaltar os aspectos qualitativos da mente. Ao avaliarmos tal "problema", delinearemos as duas perspectivas em que se coloca o 
problema, a saber: a) sua dimensão epistemológica, que consiste na problemática articulação dos discursos científico-filosófico (comumente proferido em terceira pessoa) e o mentalista (inevitavelmente de primeira pessoa); b) sua dimensão ontológica, que consiste em saber que espécie de coisas existem no mundo. 


\section{1 - O problema mente-corpo na concepção cartesiana e o bom senso como marca distintiva do humano}

Dentro do contexto geral da revolução científica do século XVII, no qual a física apontava para uma perspectiva completamente diversa e incompatível com a física aristotélica de até então, é que se situa o pensamento influente e polêmico de Descartes.

Entendemos que ma das principais características do universo cartesiano seria a identificação entre matéria e extensão. Ademais, "o mundo de Descartes é um mundo matemático rigidamente uniforme, um mundo de geometria retificada, de que nossas idéias claras e precisas nos dão um conhecimento evidente e certo" (Koyré, 1979, p. 101).

Sendo a matéria identificada à extensão, de modo que por corpos materiais, deverse-ia entender substâncias identificadas ao espaço e que seriam movidas por forças extrínsecas, o universo físico em questão seria um universo mecânico, regulado por leis físicas, que, em última análise, deveriam descrever as interações causais lineares entre corpos extensos ${ }^{4}$.

Dado este breve panorama a respeito do contexto científico do século XVII no qual se situava Descartes, interessa-nos notar que nas Meditações (1973), levando a cabo seu projeto de fundamentação do conhecimento e reorganização das ciências particulares, o filósofo conclui que além de uma realidade material (com as características arroladas acima), haveria também uma realidade imaterial que interagiria com a realidade física, constituída por entidades não extensas, que seriam responsáveis pelas faculdades racionais

\footnotetext{
${ }^{4}$ A metáfora usual da época era a do universo enquanto mecanismo de relógio, ou seja, um universo de interações por contato direto (causas lineares), com a característica de que cada corpo ocuparia um lugar no espaço, possuindo peso e medida, podendo ser geometricamente analisado.
} 
do homem. Tais entidades ou espíritos caracterizar-se-iam por serem indivisíveis, não ocupando lugar no espaço e não estando sujeitas às leis da mecânica. Em suma, Descartes postula uma ontologia dualista.

Como não poderia deixar de ser, poderosas críticas não tardaram a surgir contra as idéias cartesianas, que, grosso modo, diziam respeito ao evidente problema de se sustentar uma ontologia dualista, segundo a qual existe uma interação entre substâncias materiais e imateriais. A partir daí, pode-se dizer que estaria colocado de maneira "clara e distinta" o problema mente-corpo.

Ciente dos embaraços que sua doutrina acarreta, Descartes procura, nas Paixões da alma (1973), analisar o problema aventando à possibilidade da glândula pineal, existente no cérebro, vir a desempenhar a mediação entre a mente e o corpo ${ }^{5}$. Porém, tratando-se a glândula pineal de uma estrutura orgânica ou cerebral (portanto física) ${ }^{6}$, e, tendo em vista a inexistência de suportes conceituais e técnicos para se estudar satisfatoriamente o cérebro, as explicações de Descartes foram consideradas pouco satisfatórias.

Mas o que realmente interessa notar, para nossos propósitos, é que com a publicação das Paixões da alma, o problema geral colocado nas Meditações acerca da interação entre duas substâncias distintas se reduz ao problema (que basicamente seria o mesmo, porém, mais localizado) da interação entre mente e cérebro ${ }^{7}$.

\footnotetext{
${ }^{5}$ Retomaremos este ponto adiante, na segunda seção do presente capítulo, ao tratarmos do domínio do humano, plano em que mediante as sensações, se dá a conjugação do corpo com o espírito.

${ }^{6} \mathrm{O}$ que por si só, poder-se-ia objetar, constitui-se em enorme problema, pois o que está em questão é justamente a possibilidade de mediação entre o físico e o mental, que, presumivelmente, se daria por meio de algo não totalmente físico, tampouco, totalmente não físico.

${ }^{7}$ A rigor, seria errôneo afirmar que nas Paixões da alma o problema mente-cérebro passa a ser concebido como um caso particular do problema mente-corpo; isso porque entendemos que Descartes, em tal obra, enfatiza, sobretudo, o fígado e o coração como órgãos responsáveis pela maior parte de nossas afecções. Entretanto, ao situar o ponto de mediação da alma com o corpo na glândula pineal (uma estrutura localizada no cérebro), entendemos ser perfeitamente legítimo conceber o problema mente-cérebro como um caso particular do problema mente-corpo.
} 
O esquema apresentado na tabela 1, abaixo, bastante sucinto, resume as principais características da distinção entre corpo e alma verificadas na doutrina cartesiana :

Corpo - substância extensa que:
- ocupa lugar no espaço;
- é divisível;
- é perecível ;
-é regido pelas leis da mecânica.

A mente - substância não extensa que:
- Não ocupa lugar no espaço;
- é indivisível;
- é Imperecível e;
- Não é regida pelas leis da mecânica.

Tabela 1 - as principais características da relação mente e corpo na filosofia cartesiana. 
Em relação a última característica da mente mencionada na tabela 1 (que na verdade não chega a ser uma característica, mas sim, a negação de um conjunto de propriedades), qual seja, a não subordinação da mente às leis mecânicas, a questão que se coloca seria a seguinte: na medida em que a mente não se regula por leis da mecânica (uma sub área da física), que princípios norteariam seu funcionamento?

A este respeito, observa Descartes logo no primeiro parágrafo de seu Discurso do método (1973):

O bom senso é a coisa do mundo melhor partilhada, pois cada qual pensa estar tão bem provido dele, que mesmo os que são mais difíceis de contentar em qualquer outra coisa não costumam desejar tê-lo mais do que o têm. E não é verossímil que todos se enganem a tal respeito; mas isso antes testemunha que o poder de bem julgar e distinguir o verdadeiro do falso, que é propriamente o que se denomina o bom senso ou a razão é naturalmente igual em todos os homens; e, destarte, que a diversidade de nossas opiniões não provém do fato de serem uns mais racionais do que outros, mas somente de conduzirmos nossos pensamentos por vias diversas e não considerarmos as mesmas coisas (p. 29).

Atentando à citação que precede, entendemos que Descartes enfatiza o papel do bom senso como uma característica fundamental da razão, que, a despeito dos seres humanos conduzirem seus pensamentos por vias diversas, não considerando as mesmas coisas, ainda assim, o bom senso seria a "coisa do mundo melhor partilhada" entre os homens.

E mais adiante, continua:

E não sei de quaisquer de outras qualidades, exceto as que servem à perfeição do espírito; pois, quanto à razão ou bom senso, posto que é a única coisa que nos torna homens e nos distingue dos animais, quero crer que existe inteiramente em cada um, e seguir nisso a opinião comum dos filósofos, que dizem não haver mais nem menos senão entre os acidentes, e não entre as formas ou naturezas dos indivíduos de uma mesma espécie (p.29).

A respeito do bom senso, razão ou capacidade de discernimento que seria a marca distintiva do humano, nos tornando não apenas distintos mas superiores aos animais, 
poderíamos dizer que este se constitui no ponto crucial de sua metafísica. Assim, o que quererá Descartes dizer ao empregar semelhante expressão (bom senso)? Uma possibilidade de interpretação talvez possa ser encontrada no núcleo de sua metafísica, mais especificamente, na correlação entre livre arbítrio, moral e razão.

Sem a pretensão de esgotar a complexa cadeia de razões apresentada por Descartes em suas Meditações, podemos dizer que mediante a análise de algumas noções desenvolvidas pelo filósofo em tal obra pretendemos indicar a natureza do $e u$ ao qual se atribui o bom senso.

Assim, resumindo a "ordem das razões", ou encadeamento lógico que Descartes arquiteta nas Meditações, observa-se que partindo da dúvida metódica e radical de nossos $\operatorname{conhecimentos}^{8}$, desde o conhecimento obtido por meio dos sentidos até às ditas "verdades matemáticas" (questionadas mediante a radical hipótese de que um Deus onipotente e enganador nos leve ao equívoco acerca de tudo o que tomamos por certo, inclusive no que diga respeito a operações algébricas elementares), Descartes atinge a primeira certeza a partir da qual todas as demais poderão ser alcançadas, qual seja, a certeza do Cogito.

Depois de atingir a certeza do $e u$, Descartes, visando aprofundar o conhecimento desse eu que indubitavelmente existe enquanto ser pensante, discrimina os seguintes atributos que o caracterizam, que seriam: as faculdades de duvidar, conceber, afirmar e negar, querer e não querer, imaginar e sentir ${ }^{9}$.

Dos atributos da mente arrolados acima, entendemos que poderiam ser distinguidas quatro faculdades básicas envolvidas nas atividades do cogito ${ }^{10}$. A primeira delas poder-se-

\footnotetext{
${ }^{8}$ Em que a menor sombra de dúvida seja metodologicamente equiparada à falsidade.

9 "Mas o que sou eu, portanto? Uma coisa que pensa. Que é uma coisa que pensa? É uma coisa que duvida, que concebe, que afirma, que nega, que quer, que não quer, que imagina também e que sente" (p. 95).

10 Para entendermos um pequeno ponto do que diremos adiante sobre a terceira faculdade da alma
} 
ia dizer que diz respeito às faculdades lógicas da mente, pois ao afirmar que é uma coisa que duvida, sendo que esta coisa que duvida consiste em algo capaz de conceber, afirmar e negar, Descartes sugere que uma das capacidades da mente é a de produzir inferências.

A segunda faculdade da mente seria a vontade, pois além de ser algo que concebe, afirma e nega, o eu seria também algo que quer e não quer, algo capaz de volição em relação a diferentes objetos, sejam internos ou externos ao sujeito.

Já a terceira faculdade seria a própria da imaginação, pois, como vimos anteriormente (nota dez), ao postular a existência das idéias fictícias como sendo resultantes da "mistura" de idéias advindas da experiência, Descartes já aventava para a hipótese de uma das faculdades do cogito consistir justamente na criação de imagens mentais.

Quanto à quarta faculdade da mente, finalmente, assegura o filósofo que esta consiste na capacidade de sentir, e que entendemos se constituir num dos pontos de maior complexidade da filosofia cartesiana; isso porque mesmo admitindo que as sensações constituem-se num dos atributos da alma, Descartes nelas reconhece a capacidade de apreensão de qualidades secundárias. A este respeito, discorreremos na segunda seção do presente capítulo ao investigarmos o que se convencionou chamar de "terceiro domínio" da filosofia cartesiana, que é o domínio da união da mente com o corpo.

(imaginação), devemos por hora apenas destacar que, para Descartes, as idéias podem ser classificadas em três tipos: inatas, adventícias ou adquiridas e fictícias. As idéias inatas (como as idéias de Deus e de figuras geométricas, por exemplo), teriam sido implantadas na alma por Deus no momento do nascimento do indivíduo, e que pelo fato de serem 'claras e distintas', constituir-se-iam na melhor maneira de se atingir a verdade e evitar o erro. Além das inatas, Descartes discrimina também a existência de idéias derivadas de nossa interação com o mundo, ou as advindas da experiência. Pelo termo "experiência", Descartes concebe tudo aquilo que é percebido pelos sentidos, tudo o que aprendemos com os outros, e, de modo geral, tudo o que atinge o intelecto oriundo de fontes externas. Quanto às idéias fictícias, finalmente, temos que para Descartes, estas seriam as idéias resultantes da fusão entre duas idéias. Como exemplo podemos citar a idéia de unicórnio, que seria o resultado da união entre as idéias advindas de cavalo e de pássaro, ou a idéia de sereia, resultante da mistura das idéias de mulher e de peixe (cf. Cottinghan, 1995, verbete "idéia"). 
Feito este breve parêntese acerca dos atributos da mente ${ }^{11}$ (que nos são necessários para a compreensão do sujeito possuidor do bom senso), observamos que, alcançada a primeira certeza, da existência do eu enquanto coisa pensante, Descartes, se não desejar permanecer em solidão a examinar a certeza do conteúdo de suas próprias idéias, deve estender suas reflexões no sentido de demonstrar racionalmente a existência do mundo físico.

Para assegurar a existência do mundo físico e fundar a possibilidade do conhecimento objetivo, Descartes se empenha em demonstrar a existência de Deus através dos seus efeitos, que será a garantia da existência do mundo e do conhecimento objetivo. Expliquemos:

Apoiado numa noção muito difundida na Idade Média, a evidência das idéias claras e distintas reveladas pelo Cogito implica que deve haver tanta realidade na causa quanto em seus efeitos, de modo que a idéia de perfeição reconhecida no sujeito do conhecimento, que por ser capaz de conceber a idéia de um ser dotado de perfeição, bem como capaz de atingir a idéia clara e distinta do Cogito, deve ser o efeito de algo ainda mais poderoso e sumamente perfeito, que é Deus.

Em seguida, Descartes estabelece que a idéia de um Deus enganador não se coloca na medida que as perfeições concebidas pelo sujeito do conhecimento não poderiam advir do próprio sujeito, devendo, pois, ter advindo de um ser sumamente perfeito e veraz; isso porque a idéia de perfeição infinita atribuída a Deus seria incompatível com a hipótese de

\footnotetext{
${ }^{11}$ Talvez cause certa estranheza a não caracterização da memória como uma das faculdades da alma, que, com efeito, é concebida por Descartes como sendo em grande medida pertencente ao domínio corpóreo. Para maiores detalhes, cf. Broens, 2001.
} 
um Deus embusteiro, pois para Descartes, o embuste estaria associado ao vício, à imperfeição.

Dado o resumo dos passos seguidos por Descartes no estabelecimento da existência de Deus e sua conseqüente infinita perfeição, resta investigar a possibilidade do erro, ou seja, como pode ocorrer que em determinadas circunstâncias nos enganemos, sendo que o Deus cartesiano é onipotente e veraz? A este respeito, observa o filósofo na quarta meditação:

Assim, conheço que o erro enquanto tal não é algo de real que dependa de Deus, mas que é apenas uma carência; e, portanto, que não tenho necessidade, para falhar, de algum poder que me tenha sido dado por Deus particularmente para esse efeito, mas que ocorre que eu me engane pelo fato de o poder que Deus me doou para discernir o verdadeiro do falso não ser infinito em mim (p. 124).

Sendo que o erro, para Descartes, não se constitui numa realidade dependente de Deus, mas antes, seria uma espécie de carência do poder infinito de discernir o verdadeiro do falso, resta que o erro adviria do concurso de duas causas, a saber: do livre-arbítrio do entendimento em poder conhecer e da vontade ${ }^{12}$.

Ou seja, sendo o erro inexistente na perfeição divina, infere-se que o erro seria uma carência do homem, que tende a estender o poder de seu livre arbítrio para domínios que vão para além de seu entendimento, que não é ilimitado como o poder de sua vontade, pois o entendimento humano por mais amplo que seja é incapaz de atingir a perfeição da infinitude divina.

Em outras palavras, para Descartes, a vontade ou a capacidade de julgamento é livre e infinita; e se há o engano, ele ocorre quando a vontade é estendida para além do 
domínio das coisas compreensíveis. Em suma, o erro adviria de uma espécie de descompasso entre a vontade e o entendimento, de modo que invariavelmente se incorre em erro quando se estende o amplo poder da vontade a coisas que extrapolam os limites do entendimento $^{13}$.

Feitas tais considerações acerca de como Descartes caracteriza o livre-arbítrio humano, ou seja, como um tipo perfeição capaz de conduzir ao erro quando estendido às coisas que vão além dos limites do entendimento humano, podemos dizer que, para o filósofo, a moral seria fundamentalmente calcada no livre arbítrio, de modo que, para uma ação eficaz ou virtuosa, o sujeito deve esmerar-se ao máximo no sentido de bem conduzir sua vontade, respeitando os limites da razão.

Em carta endereçada a Elisabeth, datada de $1^{\circ}$ de setembro de 1645 (1994), ao referir-se à primeira regra moral estabelecida no Discurso do método, diz o seguinte: “A primeira é que nos esforcemos sempre por servir-nos, da melhor maneira possível, de nosso espírito, para conhecer o que devemos ou não fazer em todas as circunstâncias da vida” (p. 414).

Cabe ressaltar que tal emprego "da melhor maneira possível” de nosso espírito (cujas características mais basilares seriam a vontade e o entendimento ou razão) no que cumpre fazer em todas as circunstâncias da vida, não significa fazer uso de procedimentos racionais infalíveis, tais como o raciocínio dedutivo válido, por exemplo. Pois, como

\footnotetext{
12 "Olhando-me de mais perto e considerando quais são meus erros, descubro que dependem do concurso de duas causas, a saber, do poder de conhecer que existe em mim e do poder de escolher, ou seja, meu livrearbítrio; isto é, de meu entendimento e conjuntamente de minha vontade" (Meditações, p. 125).

13 "Donde nascem, pois, meus erros? A saber, somente de que, sendo a vontade muito mais ampla e extensa que o entendimento, eu não a contenho nos mesmos limites, mas estendo-as também às coisas que não entendo; das quais, sendo a vontade por si indiferente, ela se perde muito facilmente e escolhe o mal pelo bem ou o falso pelo verdadeiro. O que faz com que eu me engane e peque" (Meditações, p. 127).
} 
ressaltamos acerca da possibilidade do erro e como observa Descartes ainda na mesma carta: "Não é também necessário que nossa razão jamais se engane" (p. 415) ${ }^{14}$.

Com base nas idéias até aqui apresentadas, entendemos que a sugestão principal de Descartes seria a de que o domínio do entendimento não seria ilimitado. De modo que mesmo sendo capaz de atingir a "certeza" em relação à existência de Deus e ao conhecimento de suas principais propriedades (todas derivadas de sua perfeição), ainda assim, haveria pontos cegos ao entendimento.

Mesmo com a efetiva aplicação de procedimentos racionais complexos, como aqueles guiados pelas regras da lógica, mesmo que adequada em determinadas circunstâncias da vida, não poderia ser tomada como uma regra geral, passível de ser aplicada em todas as circunstâncias da vida. Pois como observa Descartes pelo termo "circunstância", o contexto se faz importante na escolha do que se deve ou não se fazer frente a determinados problemas.

Assim, a partir de uma metafísica calcada no livre arbítrio, os procedimentos racionais por excelência têm de se submeter ao tribunal da própria razão, de modo que escolhas entre o que é apropriado ou não frente a determinadas situações têm que passar pelo crivo de um critério de relevância que determine em que circunstâncias se deve seguir uma regra ou simplesmente abandoná-la.

Nesta perspectiva, entendemos que o bom senso seria justamente a capacidade fundamentalmente humana de se articular a infinita vontade com os limites do

\footnotetext{
${ }^{14}$ Como observa Lebrun em nota de rodapé referente a tal passagem: "a possibilidade de uma moral como ciência que o Discurso do método já anunciava não se coloca, pois nunca se pode, para Descartes, ter a certeza absoluta de que se optou pelo melhor" (p. 415).
} 
entendimento, mediante o estabelecimento de um critério de relevância apropriado para se decidir o que deve ou não ser adotado frente às vicissitudes da vida.

Além disso, podemos acrescentar que o pressuposto cartesiano da existência do bom senso, no emprego de um critério de relevância, não se ajusta aos pressupostos mecanicistas do século XVII por assumir o livre-arbítrio como primado. Deste modo, a seguinte questão se coloca: como seria possível, para Descartes, compatibilizar em sua filosofia o mecanicismo do mundo físico com o livre-arbítrio de sua concepção de eu metafísico? Na próxima seção analisaremos tal questão com algum pormenor. 


\section{2 - Livre-arbítrio e mecanicismo: o lugar do humano e da consciência}

Como aventamos na primeira seção, a capacidade de sentir seria um dos pontos de maior complexidade da filosofia cartesiana, na medida em que mesmo admitindo as sensações como um dos atributos da mente, o filósofo nelas reconhece a capacidade de apreensão, ou melhor, de expressão do que se convencionou chamar de qualidades secundárias.

Isso porque causa certa estranheza admitir no bojo de uma ontologia dualista que uma noção (a de sensações) esteja atrelada às operações relacionadas ao plano corpóreo, e, ao mesmo tempo, seja concebida como um dos atributos da mente. Para entendermos melhor este ponto, vejamos o que entende Descartes pela noção de pensamento:

Nas Objeções e respostas (1973), publicadas posteriormente às Meditações, onde Descartes procura responder às objeções formuladas por alguns de seus contemporâneos, a definição de pensamento é assim apresentada pelo filósofo:

\footnotetext{
Pelo nome de pensamento, compreendo tudo quanto está de tal modo em nós que somos imediatamente seus conhecedores. Assim, todas as operações da vontade, do entendimento, da imaginação e dos sentidos são pensamentos. Mas acrescentei imediatamente, para excluir as coisas que seguem e dependem de nossos pensamentos: por exemplo, o movimento voluntário tem, verdadeiramente, a vontade como princípio, mas ele próprio, no entanto, não é um pensamento (p. 179).
}

Com base nas hipóteses apresentadas na primeira seção, acerca da natureza do pensamento entendido como algo (no sentido de res) não extenso, não regido por leis da mecânica, indivisível e eterno, acrescente-se que o pensamento é tudo quanto está de tal 
modo em nós que somos imediatamente seus conhecedores ${ }^{15}$. Contudo, como ressalta Descartes, o que se segue e depende do pensamento, como o movimento voluntário causado pela vontade, por exemplo, não pode ser confundido com o próprio pensamento.

Tendo em vista as considerações de Descartes acerca das sensações, concebida como um dos atributos da mente ou como um "dos modos de ser do pensar", e atentando para a caracterização de pensamento expressa acima, infere-se que as sensações seriam uma espécie de apreensão, pelo pensamento, do que se passa no plano corpóreo, portanto do que é divisível (corpo) por algo indivisível (mente).

Porém, devemos ressaltar que no homem a apreensão de modificações corporais pela mente não se dá enquanto mera contemplação, por parte desta, de coisas que se passam num âmbito estranho e exterior; pois o domínio do humano constitui-se, para Descartes, num âmbito em que a relação mente-corpo não pode ser entendida apenas como um corpo adicionado a um espírito, tal qual um piloto e seu navio, mas também como uma mistura entre essas duas substâncias.

Na sexta Meditação, com efeito, observa Descartes:

\begin{abstract}
A natureza me ensina, também, por esses sentimentos de dor, fome, sede, etc., que não somente estou alojado em meu corpo, como um piloto em seu navio, mas que, além disso, lhe estou conjugado muito estreitamente e de tal modo confundido e misturado, que componho com ele um único todo. Pois, se assim não fosse, quando meu corpo é ferido não sentiria por isso dor alguma, eu que não sou senão uma coisa pensante, e apenas perceberia esse ferimento pelo entendimento, como o piloto percebe pela vista se algo se rompe em seu navio; e quando meu corpo tem necessidade de beber ou de comer, simplesmente perceberia isto mesmo, sem disso ser advertido por sentimentos confusos de fome e de sede. Pois, com efeito, todos esses sentimentos de fome, de sede, de dor, etc., nada são exceto maneiras confusas de pensar que provém e dependem da união e como que da mistura entre o espírito e o corpo (p. 144).
\end{abstract}

\footnotetext{
${ }^{15}$ Adiante, ao discutirmos com algum pormenor a noção de consciência, veremos que para Descartes, grosso modo, estar consciente consistiria essencialmente em acessar direta e constantemente os conteúdos do próprio pensamento, mais ou menos como se constantemente lançássemos um facho de luz sobre os atores de um teatro privado.
} 
O que ressalta Descartes na citação acima é que além do domínio do mecanicismo característico dos corpos, e da vontade infinita da res cogitans, haveria também um terceiro domínio, o da conjugação estreita entre corpo e espírito, expresso unicamente no gênero humano. De tal conjugação entre o divisível e o indivisível existente no humano, resultaria o que Granger (1973) entende como "o caráter radicalmente obscuro e confuso, mas perfeitamente autêntico em seu gênero, da sensação, que apreende qualidades e não essências objetivas" (p. 22).

A confusão no domínio das sensações deriva do caráter ambíguo que cerca a noção de paixão (que seria afecções da alma produzidas por modificações corporais que a incitam a querer coisas para as quais prepara o corpo). Isso porque as paixões, em Descartes, situarse-iam na encruzilhada da relação mente-corpo ${ }^{16}$.

Tal confusão no domínio do sentimento aumenta quando se considera que os diferentes tipos de paixões existentes estariam sujeitos a uma espécie de gradação que faz com que, por exemplo, o sentimento de benevolência expresse maior livre-arbítrio que o sentimento de cólera. Sendo assim, de modo geral, Descartes entende que as pessoas que manifestam sentimentos elevados (tais como o amor ou a compaixão, por exemplo) expressariam melhor o livre-arbítrio, estando menos suscetíveis ao mecanicismo associado às paixões mais escusas, tais como a cólera ou a inveja.

Além disso, a relação entre as paixões e o pensamento (em especial a vontade) não obedece a uma lógica pré-determinada do tipo: ante uma situação de perigo, o melhor é fugir. Pois a despeito do comum das pessoas cederem às suas paixões, fugindo ante o

\footnotetext{
${ }^{16}$ Como indicamos (seção 1), nas Paixões da alma, Descartes entende que a mediação entre corpo e espírito ocorreria na glândula pineal, e dar-se-ia por meio dos espíritos animais, que seriam como que as partes mais fluidas do sangue que, circulando do coração para o cérebro, e, deste para os músculos, funcionariam como
} 
perigo, haveria pessoas inspiradas por heroísmo que, ao exercê-lo, resistiriam às suas paixões e enfrentariam o risco de morte ${ }^{17}$.

Deste modo, pode-se dizer que para Descartes, aqueles que bem conduzem seus pensamentos, exercitando sua vontade e poder de resolução, estariam mais distanciados do automatismo (característico do plano corpóreo) que pessoas irresolutas ou mais suscetíveis de ceder ante as paixões; pois como afirma em seu último artigo da primeira parte das Paixões da alma: “(...) mesmo aqueles que possuem as almas mais fracas poderiam adquirir um império absoluto sobre todas as suas paixões, se empregassem bastante engenho em domá-las e conduzi-las (p. 97)”.

Por tratarem-se as paixões de fenômenos estritamente psicofísicos, pode-se dizer que, para Descartes, no caso dos animais, dado que estes não possuem mente ou razão, também não possuiriam paixões, de modo que teriam suas ações regidas exclusivamente por meros automatismos. Ou seja, faltando-lhes alma, a possibilidade dos animais possuírem bom senso e sensações estaria excluída; e o mesmo ocorreria com os autômatos, que, nesta perspectiva, não manifestariam bom senso ou propriedades mentais, mesmo que suas partes constitutivas estejam dispostas de tal modo que sejam capazes de executar todos os movimentos que os seres humanos são capazes de executar.

mecanismos hidráulicos capazes de mover os corpos humanos. E como também já apontamos, sendo a glândula pineal uma estrutura física, as explicações de Descartes foram consideradas não muito convincentes.

${ }_{17}$ Entretanto, devemos deixar claro que para Descartes, nossas paixões só podem ser excitadas ou inibidas pela nossa vontade de modo indireto: "Nossas paixões também não podem ser diretamente excitadas nem suprimidas pela ação de nossa vontade, mas podem sê-lo, indiretamente, pela representação das coisas que costumam estar unidas às paixões que queremos ter, e que são contrárias as que queremos rejeitar. Assim, para excitarmos em nós a audácia e suprimirmos o medo, não basta ter a vontade de fazê-lo, mas é preciso aplicar-nos a considerar as razões, os objetos e os exemplos que persuadem de que o perigo não é grande; de que há sempre mais segurança na defesa do que na fuga; de que teremos a glória e a alegria de havermos vencido, ao passo que não podemos esperar da fuga senão o pesar e a vergonha de termos fugido, e coisas semelhantes" (p. 157). 
Na quinta parte do Discurso do método, Descartes ressalta que existiriam dois

testes que permitem distinguir os homens das máquinas e dos animais.

\author{
[primeiro teste]
}

O primeiro é que nunca poderiam usar palavras, nem outros sinais, compondo-os, como fazemos para declarar aos outros os nossos pensamentos. Pois pode-se muito bem conceber que uma máquina seja feita de tal modo que profira palavras, e até que profira algumas a propósito das ações corporais que causem qualquer mudança em seus órgãos: por exemplo, se a tocam num ponto, que pergunte o que se lhe quer dizer; se em outro, que grite que lhe fazem mal, e coisas semelhantes; mas não que ela os arranje diversamente, para responder ao sentido de tudo quanto se disser na sua presença, assim como podem fazer os homens mais embrutecidos (p. 68).

Ou seja, para Descartes, o plano lingüístico (característica essencial do humano)

não seria passível de ser efetuado por máquinas reguladas por leis estritamente mecânicas,

pois lhes faltaria o bom senso. E o mesmo valeria para o plano da ação. Ainda na mesma página da quinta parte do Discurso do método, prossegue Descartes:

\title{
[segundo teste]
}

E o segundo é que, embora fizessem muitas coisas tão bem, ou talvez melhor do que qualquer um de nós, falhariam infalivelmente em algumas outras, pelas quais se descobriria que não agem pelo conhecimento, mas somente pela disposição de seus órgãos. Pois, ao passo que a razão é um instrumento universal, que pode servir em todas as espécies de circunstâncias, tais órgãos necessitam de alguma disposição particular; daí resulta que é moralmente impossível que numa máquina existam bastante diversas para fazê-la agir em todas as ocorrências da vida, tal como a nossa razão nos faz agir (p. 68-69).

Também não bastando, no plano da ação, o mero arranjo ordenado das peças, o fato é que, para Descartes, sem o bom senso não se poderia agir racionalmente em todas as ocorrências da vida, tal como a nossa razão nos faz agir. Dada a caracterização do domínio 
do humano, com especial ênfase ao contraste deste em relação aos animais e autômatos, passemos a outro ponto.

Tendo em vista o que pudemos observar acerca da ontologia dualista cartesiana em especial, das propriedades da mente ou coisa pensante, que, em contraste com o mecanicismo que rege o funcionamento do corpo, seria marcada seja pelo livre arbítrio, seja pela capacidade de produzir inferências e ter sentimentos - cremos ser possível efetuar algumas observações importantes no que tange à noção de consciência.

Tomando o dualismo ontológico como primado, segue-se que Descartes, frente à dificuldade (senão impossibilidade) de explicar convincentemente a maneira como se daria, nos seres humanos, a comunicação da alma com o corpo, acaba por estabelecer uma espécie de "vida dupla", em que a despeito da incompreensível conjugação da alma com o corpo (o terceiro domínio do humano e que se expressa, sobretudo, mediante os sentimentos), o que restaria é a privacidade de um mundo mental que contrasta com a exterioridade do movimento corpóreo que é eminentemente público e mecanicamente regido.

Se por meio da percepção sensorial é possível ao homem acessar o que se passa no espaço ou esfera pública, o que se passa no espírito também seria passível de ser acessado mediante uma espécie de "percepção interna" muito mais eficaz e completa, que dispensaria o uso dos "canhestros" órgãos sensoriais, sempre sujeitos ao equívoco, como bem sugere Descartes em sua segunda meditação.

Mas independentemente de se poder tomar erroneamente certas experiências que se passam nos sonhos como "experiências reais" ou experienciadas em vigília, bem como incorrer-se em erro no tocante à teorizações (principalmente quando se estende a vontade às coisas além do entendimento), pode-se dizer que para Descartes, inequivocamente, a apreensão constante dos próprios pensamentos estaria assegurada a todos. 
Inequivocamente, não apenas no sentido de que determinados conteúdos mentais podem ser investigados ou "percebidos não sensorialmente" mediante introspecção, mas também no sentido de que algo está sempre a ocupar o pensamento, ou seja, de que os espíritos jamais podem ignorar a presença dos atores que constantemente encenam em seu teatro privado, pois como mencionado, o pensamento seria "tudo quanto está de tal modo em nós que somos imediatamente seus conhecedores".

Para que as afirmações efetuadas acima pareçam menos nebulosas, façamos algumas distinções importantes entre introspecção e consciência.

Julgamos que a principal diferença entre introspecção e consciência, na filosofia cartesiana, seria a de que a introspecção é uma atividade mental que ocorre apenas eventualmente, quando atentamos ou "percebemos intelectualmente" determinados conteúdos mentais, geralmente, quando buscamos a solução para determinados problemas particulares. Já a consciência, seria um elemento constante de nossos processos mentais, que não requer necessariamente atos especiais de atenção para ser captado (Ryle, 2000, p. 164).

Dado que a introspecção seria uma "atenção ocasional" dirigida aos conteúdos da mente, e que a consciência caracterizar-se-ia por ser um conhecimento constante dos atores que encenam num mundo privado, este "teatro privado" deve ser tomado em sentido extremamente forte, ou seja, no sentido de que, para Descartes, o conhecimento evidente que cada qual tem de suas vontades, emoções e operações intelectuais (sempre passíveis de serem examinadas acuradamente mediante introspecção) não pode ser estendido ao domínio de outras mentes.

Nesta perspectiva, cada mente bastaria a si mesma, estando, pois, intrinsecamente ligada a seu próprio domínio corpóreo e impossibilitada de acessar diretamente o conteúdo 
de outras mentes. Isso porque cada mente seria uma unidade singular e autônoma, com acesso privilegiado e evidente somente de seus próprios conteúdos.

Uma conseqüência do internalismo introspectivo é que o conhecimento da existência de outros espíritos e do que neles se passa só pode ser inferido de maneira muito superficial e precária, pois não podendo se dar de maneira direta dar-se-ia indiretamente (com o auxílio dos sentidos) por meio da análise do comportamento dos corpos alheios. Superficialidade e precariedade provenientes não apenas da impossibilidade de acesso direto ao espírito alheio, mas também das limitações dos sentidos, sempre passíveis de induzirem ao erro. Em suma, feitas tais observações, nota-se que o solipsismo estaria permanentemente no horizonte de uma perspectiva filosófica dualista, tal qual o cartesianismo.

Entretanto, cabe ressaltar que o que as considerações acima acerca do solipsismo enquanto "dificuldade teórica", não se afigura enquanto consenso, mesmo no seio de posições de inspiração materialista, tal como o funcionalismo. Putnam (1975), por exemplo, entende que para se compreender a mente deve-se pressupor a idéia de que o conteúdo de um dado estado mental em nada depende de algo externo à mente que o entretém; a tal posição chamará de solipsismo metodológico, segundo a qual, reiteramos, o acesso a nenhum estado psicológico pressupõe a existência de qualquer outra mente que não a do próprio indivíduo a quem este estado é atribuído (Putnam, 1975, p. 225).

Da exposição e análise que fizemos acerca de diversos tópicos da filosofia cartesiana, cremos ser possível efetuar algumas observações que servirão de ponto de partida para nossa posterior discussão do problema mente-corpo.

A primeira delas seria que, estabelecida enquanto grave problema, sobretudo, a partir da filosofia cartesiana, a relação mente-corpo comporta dois planos de análise, a 
saber: uma perspectiva ontológica e uma epistemológica. Essas distinções serão explicitadas na próxima seção, ao discorrermos sobre a maneira como se coloca contemporaneamente o problema mente-corpo.

Uma segunda observação seria que a ciência cognitiva e filosofia da mente contemporâneas tendem a enfatizar que o problema mente-corpo se coloca de maneira contundente quando se pensa em como se daria a relação entre a experiência das chamadas qualidades secundárias da mente com os suportes neurobiológicos que as produzem e a linguagem que as expressa.

Tal concepção de uma problemática relação da experiência com o cérebro e o modo como se expressa uma experiência particular, se coloca como o problema da consciência enquanto expressão da relação mente-corpo; isso porque, contemporaneamente, convencionou-se atrelar a noção de consciência à experiência. Além disso, certos autores como Chalmers (1996), por exemplo, entendem que a relação entre experiência e consciência constitui o problema realmente difícil das ciências da mente e filosofia contemporâneas. Entraremos em detalhes sobre este ponto adiante, na próxima seção do presente capítulo. 


\section{3 - A formulação contemporânea do problema mente-corpo}

Numa linguagem contemporânea, o problema mente-corpo pode ser formulado da maneira como se segue: como seria possível que algo material (o cérebro, no caso) passível de ser "visto", ou seja, que pode ser medido, dividido, "pinçado" e classificado mediante leis científicas, poderia agir (no sentido de que causaria ou até mesmo sentiria os efeitos) sobre algo extremamente difícil (para alguns impossível) de ser "pinçado" ou mensurado por meio dos mesmos instrumentos de análise da biologia, química ou da física?

De modo menos direto, o problema mente-corpo se coloca quando se tenta explicar como determinados estados qualitativos da consciência tais como a sensação do sabor, temperatura, textura e aroma do café que agora bebo, por exemplo, se relacionam com meu corpo (cérebro).

É claro que por meio de um discurso partilhável intersubjetivamente, poderíamos relatar essa nossa experiência dizendo coisas do tipo: o café que agora bebo possui um "leve amargor" característico de um café bem encorpado, uma temperatura bastante quente a ponto de produzir dor em minha língua caso beba goles além de um certo nível (medido em mililitros), uma textura "macia" ou "fluida", e um aroma um tanto quanto "adocicado".

Desse nosso relato acerca da sensação de se experimentar uma xícara de café deve-se atentar para a idéia de que tal sensação ocorreria sempre para alguém em particular. E ainda: este alguém, não podendo ser concebido como mera abstração, estando, pois, encorporado e situado em seu meio ambiente, experimentaria tais sensações num dado momento (aqui e agora), e em certos locais específicos: língua e narinas, por exemplo. 
Como bem expressa o poeta e dramaturgo espanhol Galdós (1960): “A experiência é uma chama que só ilumina queimando" (p. 14) ${ }^{18}$.

Além disso, interessa notar a dificuldade existente na descrição de tais sensações tendo em vista a necessidade de se manter um discurso compreensível inclusive àqueles que nunca tomaram café; pois a despeito da possibilidade de se medir com um termômetro a temperatura "real" do café, como seria possível descrever em termos objetivos as sensações relatadas em termos gustativos de "leve amargor", a sensação térmica de sua temperatura, a "maciez" e "fluidez" de sua textura, ou ainda, o caráter "adocicado" de seu aroma?

Tendo em vista o que salientamos nas linhas acima, interessa atentar para a idéia de que certos autores entendem que parece haver uma certa assimetria entre o discurso dito científico e o discurso que se propõe a descrever as sensações de se tomar um simples cafezinho, como em nosso exemplo ${ }^{19}$.

Isso porque, em geral, presume-se que o discurso científico é muito bem sucedido quando se refere a tipos, e limitado no trato de casos particulares (sobretudo em questões de ordem psicológica), além de ser mais persuasivo e cumprir melhor seu papel quando articulado em terceira pessoa, descrevendo fenômenos partilháveis intersubjetivamente, mediante a exigência de que tais fenômenos possam ser reproduzidos em locais e circunstâncias diversas ${ }^{20}$.

\footnotetext{
18 "La experiencia es una llama que solo ilumina quemando".

${ }^{19}$ Poderíamos chamar de mentalista tal tipo de discurso.

${ }^{20}$ É claro que fornecer uma definição esquemática do conhecimento científico constitui-se sempre numa tarefa extremamente problemática, na medida em que, dependendo da perspectiva epistemológica adotada, alguns aspectos podem ser superestimados ou negligenciados. Assim, de modo muito geral, poderíamos fornecer as seguintes características que o compõem (fornecidas por Pereira Júnior em aula): universalidade, sistematicidade, testabilidade, analiticidade, instrumentação, matematicidade, criticidade, objetividade.
} 
Ao ressaltarmos que o discurso científico refere-se a tipos, sendo limitado ou "não se sentindo a vontade" no que toca à descrição e explicação de casos particulares, poder-seia objetar que casos particulares existem, e, de fato, são objetos de estudos científicos. Um exemplo atual seria o da relação entre as alterações climáticas verificadas nas últimas décadas decorrentes da ação humana na natureza. Isso porque se constitui num caso particular a progressiva intervenção do homem na natureza sobretudo, a partir da revolução industrial do século XVIII.

Entretanto, como indicamos, sobretudo nos casos de ordem psicológica - quando se trata de descrever e explicar em detalhes determinadas ocorrências mentais, no mínimo inusitadas, tais como casos de sinestesia, em que, por exemplo, enxerga-se determinadas cores ao se ouvir uma dada nota musical - certos autores como Nagel (1974) e Jackson (1982, 1986), só para citar dois exemplos bem conhecidos, entendem que a qualidade associada à experiência subjetiva como que "se sobrepõe", ou melhor, ultrapassa o discurso, só podendo ser minimamente descrita mediante metáforas ou desfiguradoras aproximações, que, inevitavelmente, não dariam conta de expressar todas as informações que se pode obter da experiência nela mesma ${ }^{21}$.

\footnotetext{
${ }^{21}$ De maneira muito sumária, entendemos que Nagel (1974) se ocupa, fundamentalmente, com a articulação de argumentos críticos à redução do mental ao físico; e para tanto, ele sustenta que existe um determinado tipo de conhecimento que jamais poderá ser alcançado pelo materialismo, qual seja, o conhecimento de ser como "what is it like" um outro ser que não nós próprios (em especial, se este ser se tratar de uma criatura bastante distinta de um humano, como um morcego, que é o exemplo explorado por Nagel). Para Nagel, o critério de "experiência intersubjetiva direta" que o conhecimento de ser como X encerra, solapa a possibilidade da ciência contemporânea explicar uma parcela importante dos problemas existentes na natureza. Numa linha de raciocínio similar (talvez mais radical, na medida em que não se restringe a apontar as limitações do materialismo, mas vai além], no sentido de que as dificuldadess do materialismo evidenciam seu caráter equivocado), Jackson $(1982$, 1986) sustenta que o materialismo não pode tratar de todos os aspectos informacionais disponíveis no mundo, em especial, as informações relativas aos Qualia. Em seu clássico experimento de pensamento, ele indaga se seria possível que uma cientista que soubesse tudo acerca dos fenômenos físicos e neurofisiológicos concernentes às cores e seu processamento no cérebro, estando ela confinada a vida toda numa sala preta e branca, obteria, caso saísse da sala, algum acréscimo informacional com a nova experiência subjetiva das cores que, teoricamente, tão bem conhece. A resposta do autor, como é de esperar, será que sim, um acréscimo informacional importante ocorreria, e que seria impossível de ser
} 
Ou seja, a riqueza e complexidade de uma dada experiência, ao ser "trazida" ao entendimento de terceiros por meio do discurso como que perderia, em tal trajeto, parte da complexidade, riqueza e vivacidade que a caracteriza. Essa relação (tida como incompatível por certos autores) entre o discurso de terceira pessoa (conveniente na descrição de fenômenos físicos, químicos e biológicos, por exemplo) e o discurso mentalista, configurase como um problema de ordem epistemológica da relação mente-corpo ${ }^{22}$.

Um outro ponto referente à dimensão epistemológica do problema mente-corpo a ser ressaltado ${ }^{23}$ seria que o discurso mentalista (desde que entendido enquanto problemático pelas razões apontadas acima) também proporcionaria o surgimento do problema das outras mentes; ou seja, um problema que Austin (1975), coloca da seguinte maneira: "como sabemos que outra pessoa está zangada? Nós (alguma vez) conhecemos?, Podemos conhecer?, Como podemos conhecer? Os pensamentos, sentimentos, sensações, a mente, etc., de outra criatura, e assim por diante" (p. 93).

De maneira literária, o problema das outras mentes poderia ser assim concebido:

Vivemos, agimos e reagimos uns com os outros; mas sempre, e sob quaisquer circunstâncias, existimos a sós. Os mártires penetram na arena de mãos dadas; mas são crucificados sozinhos. Abraçados, os amantes buscam desesperadamente fundir seus êxtases, isolados em uma única autotranscendência, debalde. Por sua própria natureza, cada espírito, em sua prisão corpórea, está condenado a sofrer e gozar em solidão. Sensações, sentimentos, concepções, fantasias - tudo isso são coisas privadas e, a não ser através de símbolos, e indiretamente, não podem ser transmitidas. Podemos acumular informações sobre experiências, mas nunca as próprias experiências. Da família à nação, cada grupo humano é uma sociedade de universos insulares (Huxley, 1973, p. 3).

obtido dentro da perspectiva materialista da ciência tradicional. Desenvolveremos mais detalhadamente tais pontos adiante, no terceiro capítulo, especialmente o argumento de Nagel.

${ }_{22}$ É claro que a relação entre os dois tipos de discurso descritos acima só se coloca enquanto um problema caso se concorde com a concepção de que eles sejam, de fato, incompatíveis.

${ }^{23}$ Que já mencionamos de maneira um tanto apressada no primeiro capítulo. 
Feitas algumas distinções de caráter epistemológico que julgamos relevantes entre os discursos científico e mentalista, passemos agora à dimensão ontológica do problema mente-corpo.

Como alguns autores vêm salientando, em especial Levine (1983), mesmo obtendo-se o conhecimento pormenorizado dos correlatos neurais que sustentam determinados aspectos da consciência, ainda assim, parece haver uma espécie de abismo entre tais correlatos e a experiência dos estados conscientes, principalmente, no que diz respeito às qualidades secundárias ou qualia experimentados ${ }^{24}$. Ou seja, a idéia por trás do problema do explanatory gap é basicamente a mesma aventada por Nagel (1974), Chalmers (1996, 1997) e Searle (1997, 1998), entre outros, qual seja: a de que aparentemente não há característica física conhecida que se possa correlacionar ${ }^{25}$ a estados subjetivos, tais como a percepção de cores, odores, etc. É como se a história explicativa que vai dos estados neuronais aos estados conscientes desse, em algum momento, um salto inexplicado ${ }^{26}$.

Dito isso, observa-se que devido a tais "assimetrias" entre o físico e o mental (seja na dimensão epistemológica, bem como na dimensão ontológica do problema), pareceu apropriado a muitos autores afirmar que as categorias com as quais nos referimos aos fenômenos físicos seriam insatisfatórias para fornecer uma adequada descrição de certos

\footnotetext{
${ }^{24}$ Abismo explicativo (explanatory gap, em inglês) seria a expressão utilizada para designar o que chamamos acima de abismo entre os estados neurais e a experiência dos estados mentais conscientes.

${ }^{25}$ Correlacionar, no sentido de explicar como o cérebro causa ou manifesta os estados mentais, em especial, as qualidades associadas a eles.

${ }^{26}$ Acerca do abismo explicativo que resumimos acima, uma maneira de compreendê-lo seria situá-lo como estando presente na encruzilhada da transição da quantidade para a qualidade; ou como expressa Wittgenstein: "Olhe uma pedra e imagine que ela tenha sensações! - Alguém diz: Como é que se pode chegar à idéia de atribuir uma sensação a uma coisa! Poder-se-ia atribuí-la, igualmente a um número! - Olhe agora uma mosca irrequieta, e esta dificuldade desaparece imediatamente e a dor parece poder atacar aqui, onde tudo antes estava contra ela, por assim dizer, sem dificuldade. E assim também nos parece que um cadáver é completamente inacessível à dor. - Nossa atitude frente a um ser vivo não é a mesma que diante de um ser morto. Todas as nossas reações são diferentes. - Se alguém diz "isto não pode simplesmente residir no fato de que um ser vivo se movimenta desta e daquela maneira e o ser morto não" - então quero fazê-lo entender que aqui se dá a passagem da quantidade para a qualidade" (Investigações filosóficas, 1996, p. 134-5).
} 
fenômenos que experimentamos subjetivamente pelo fato do mundo físico e o mundo mental se constituírem, de fato, em realidades distintas.

Em relação à posição dualista exposta no parágrafo acima, cujo maior sistematizador teria sido Descartes, podemos dizer que, apesar de ter sido sustentada em determinados círculos influentes ainda nos séculos XVII e XVIII, perdeu de tal modo seu fôlego nos séculos subseqüentes a ponto de, contemporaneamente (pelo menos no contexto das filosofias analítica e da mente), parece ir à contramão das correntes principais aqueles que, arrogando-se a um discurso que se pretenda naturalista, sustentam hipóteses similares. Falar de mente hoje em dia (em especial, no contexto da disseminação do naturalismo filosófico expresso nas teorias da mente materialistas contemporâneas), sem considerar um substrato material que a sustente, seria problemático.

Neste ponto, é preciso que reflitamos um pouco. Pois, se na base do problema mente-corpo existe, como certos autores afirmam, ou parece haver uma assimetria entre o que comumente se entende por fenômenos físicos e fenômenos mentais, como então o dualismo poderia ser descartado assim tão facilmente, na medida em que a mera constatação de tais assimetrias parece corroborar a posição dualista?

A tarefa principal consistiria, em resumo, em analisar a natureza de tais assimetrias; ou seja, seria preciso investigar se tais assimetrias se constituem em meras aparências passíveis de serem desfeitas mediante a aplicação das hipóteses do reducionismo fisicalista, uma reorganização da geografia lógica dos conceitos, ou se tais assimetrias seriam reais, como pensam, por exemplo, os dualistas. Neste último caso, por sua vez, restaria desvendar a natureza da realidade que conferimos a tais assimetrias, ou seja, restaria saber se se trata de um dualismo de substâncias, na esteira do platonismo e 
cartesianismo, ou se trata de um dualismo de propriedades, como pensa Davidson (1991), por exemplo.

Pode-se objetar àqueles que sustentam haver, de fato, uma assimetria entre o físico e o mental, que os avanços recentes da ciência no que tange à compreensão de doenças psicossomáticas, do efeito placebo, etc., tendem a eliminar, ou no mínimo enfraquecer sensivelmente tais assimetrias. Entretanto, poder-se-ia retrucar, como de fato o faz uma gama sensível de filósofos contemporâneos: a despeito de a ciência avançar no que diz respeito ao diagnóstico e tratamento de doenças psicossomáticas, o problema de como se dá a transição da quantidade para a qualidade, ou superação do abismo explicativo, permanece sem resposta. Retomaremos adiante tais reflexões.

Da forma como foi apresentado o problema mente-corpo, evidencia-se a ênfase conferida ao problema dos estados qualitativos da consciência. Porém, devemos ressaltar que estados mentais conscientes podem ser classificados em pelo menos (até onde sabemos) duas maneiras; assim, façamos um breve parêntese e vejamos quais seriam os modos de concebê-los.

Uma maneira de conceber os estados mentais conscientes diria respeito aos estados qualitativos da consciência (exemplificado acima com nosso exemplo do cafezinho); já a segunda maneira de nos referirmos aos estados mentais conscientes seria concebê-los enquanto atitudes proposicionais, que "seriam estados mentais dotados de conteúdos representacionais. A crença é o mais proeminente exemplo de atitude proposicional. Outros incluem intenção, desejo, esperança e temor, o que me parece e o que se apresenta, além de pressuposições tácitas” (Stalnaker, 1999). Ou seja, cada um dos estados mentais expressos acima (crença, desejo, intenção, etc.) possuem um significado ou conteúdo proposicional 
específico. Ademais, tais estados mentais são chamados de atitudes proposicionais porque eles expressam, cada qual, uma atitude particular com relação a uma proposição específica.

Como exemplos de atitudes proposicionais, pensemos na seguinte proposição proferida por um amigo: "há um elefante rosa na sala ao lado". Em relação a esta estranha proposição poderíamos ter as seguintes atitudes mentais (dentre outras possíveis): "que pena, meu amigo ficou louco de vez", ou ainda: "talvez ele esteja usando drogas demais, estou preocupado", ou então: "como ele nunca mentiu para mim, talvez haja, de fato, um elefante rosa na sala ao lado. Que medo!"’.

Um outro ponto a ser ressaltado em relação às atitudes proposicionais seria o de que na tradição filosófica convencionou-se entender que os estados mentais de pesar, preocupação e medo, expressos no exemplo acima, seriam dotados de intencionalidade ${ }^{27}$, no sentido de que visam ou apontam para estados de coisas existentes ou não no mundo.

Feito este breve parêntese em que procuramos descrever sucintamente os dois modos de se conceber os estados mentais conscientes, voltemos a discorrer sobre a caracterização do problema mente-corpo na perspectiva que ressalta as qualidades associadas à experiência. Assim sendo, podemos dar continuidade à discussão ressaltando que, no contexto da filosofia da mente do século $\mathrm{XX}$, os complexos problemas que viemos delineando na presente seção acerca das perspectivas ontológica e epistemológica da relação mente-corpo (manifestas no estudo das sensações) foram inicialmente abordados por teóricos de orientação materialista que visavam identificar o mental ao cerebral. Assim, vejamos no próximo capítulo como se efetuaram tais estudos, sobretudo, nas perspectivas

\footnotetext{
${ }^{27}$ Cabe ressaltar que a acepção aqui empregada de intencionalidade não significa fazer algo de modo deliberado.
} 
de Smart e P. M. Churchland, e analisemos quais seriam as qualidades e limitações de tais abordagens. 
Capítulo 2 - Abordagens materialistas da mente: teorias da identidade e eliminativismo 


\section{Apresentação}

Neste capítulo, analisaremos, na seção 1, a teoria da identidade mente-cérebro tal como Smart (1970) a propõe. Argumentaremos que com sua proposta de identificar o mental ao cerebral (o que daria margem para se pensar numa espécie de "economia ontológica"), a possibilidade de tradução da lógica inerente ao discurso mentalista a uma lógica "cerebralista" não estaria assegurada.

Ainda na mesma seção, apresentaremos uma vertente do materialismo calcado na esperança de que o avanço das neurociências culmine na completa elucidação do funcionamento do cérebro. Deste modo, para os eliminativistas (nome comumente dado a esta vertente materialista de orientação neurobiológica), cujo autor a ser estudo é P. M. Churchland, o vocabulário mentalista característico da psicologia popular tenderia a desaparecer gradativamente, à medida que os avanços das neurociências culminem na completa elucidação do funcionamento do cérebro.

Na segunda seção, avaliaremos, num primeiro momento, algumas objeções dirigidas às respectivas abordagens estudadas, e, na seqüência, discorreremos sobre uma objeção mais geral que pode ser dirigida ao materialismo enquanto orientação filosófica. 


\section{1 - Propostas materialistas de entendimento da relação mente-corpo}

Como aventamos no primeiro capítulo, o legado da filosofia cartesiana foi o de uma concepção dualista da natureza em que a questão da unificação entre mente e corpo aparecia como o grande problema a ser superado. Tal problema da unificação, na filosofia, culminou seja em perspectivas de resolução do problema mediante a adoção de algum tipo de materialismo seja para uma perspectiva de feição idealista. $\mathrm{O}$ grande entrave para uma precisa caracterização da mente se devia, sobretudo, às suas características essencialmente subjetivas tão enfatizadas pelo cartesianismo, que averiguamos nas duas primeiras seções do capítulo precedente.

Tal estado de coisas pode-se dizer, permeou os estudos relativos à mente nos séculos subsequientes, a ponto de Browster, na metade do século XIX, afirmar o seguinte:

\footnotetext{
Não há nenhum departamento do conhecimento no qual tão pouco progresso tenha sido feito como no da filosofia da mente. A mente humana tem sido estudada como independente do corpo, e, de uma forma geral, por filósofos que possuem uma quantidade relativamente escassa de conhecimento físico. $\mathrm{Na}$ verdade, não foi feita nenhuma tentativa de examinar seus fenômenos à luz do experimento e da observação, ou analisá-los em suas fases de anormalidade... Sem dados, sem axiomas, sem definições [a ciência da mente] propõe problemas que não consegue resolver (Browster, 1854, apud Vicentini, 1999).
}

Essa perspectiva desestimulante veio a mudar significativamente em fins do século

XIX, com o surgimento das primeiras tentativas de compreensão dos fenômenos mentais em termos de experimentação ou estabelecimento de critérios objetivos de estudo. Com o 
advento da psicologia científica ou behaviorismo psicológico, tais critérios objetivos de estudo acerca da mente finalmente se estabeleceram ${ }^{28}$.

A formulação contemporânea do problema mente-corpo (apresentada na última seção do capítulo precedente) tende a ressaltar uma assimetria entre os aspectos qualitativos da consciência e a constituição corporal, não se colocava aos behavioristas em virtude do recorte epistemológico adotado por estes de coibir qualquer tipo de menção ao que não fosse passível de ser investigado unicamente em termos de comportamentos publicamente observáveis ou influencias ambientais; ou seja, ao que não fosse fundamentalmente objetivo (por mais problemática que seja a noção de objetividade).

Por volta dos anos 50 e 60, com o advento da psicologia cognitiva e conseqüente introdução da teoria da informação nos estudos da mente, ocorre a abertura da "caixa preta", ou melhor, a mudança do paradigma comportamental pelo cognitivo, que se propõe a investigar os processos "ocultos" superiores, tais como o modo como percebemos o mundo, produzimos a linguagem e os raciocínios ditos de alto nível.

Nesse contexto, surgem hipóteses desenvolvidas na filosofia da mente segundo as quais, as assimetrias a que fizemos menção seriam meramente ilusórias, devendo, pois, serem desfeitas mediante o estudo sistemático do cérebro, que, em última análise, é "apenas" um órgão estritamente material. Nessa perspectiva, comumente denominada materialismo, é que se inserem as abordagens que doravante analisaremos.

\footnotetext{
28 "Foi somente no final do século XIX que a psicologia adquiriu o status de ciência. O abandono progressivo da idéia de que a psicologia tinha sua única fonte de conhecimento em relatos subjetivos e o inicio do estudo sistemático, através da observação e experimentação do comportamento dos organismos complexos em diferentes condições ambientais, consolidam a cientificidade dessa disciplina” (Soares, 2000, p. 18).
} 
Smart (1970a), por exemplo, afirma que, em se assumindo os resultados científicos

que apontam para a idéia de que os organismos devem ser vistos como arranjos complexos

de um mecanismo físico-químico, restaria encontrar um lugar aos assim chamados estados

de consciência:

Parece-me que a ciência está cada vez mais fornecendo-nos um ponto de vista pelo qual os organismos são capazes de serem vistos como mecanismos físicoquímicos. (...) Quando levamos em consideração a ciência, tudo o que existe no mundo seriam arranjos cada vez mais complexos de constituintes físicos. Exceto em um lugar: na consciência. Ou seja, para uma completa descrição do que está acontecendo em um homem, teríamos que mencionar não apenas os processos físicos de seus tecidos, glândulas, sistema nervoso e assim por diante, mas também seus estados de consciência: suas sensações visuais, auditivas e táteis, seus sofrimentos e dores (Smart, 1970a, p. 53) ${ }^{29}$.

Na citação que precede, Smart ressalta que, tendo em vista os avanços científicos capazes de descrever os organismos como mecanismos físico-químicos, restaria desvendar (em termos científicos) os estados de consciência.

Deste modo, poder-se-ia pensar os fenômenos da consciência a partir de pelo menos duas perspectivas: ou a consciência estaria fora do plano de explicação oferecido pela ciência, de modo que tudo o que a ciência poderia fazer é estabelecer meros correlatos entre a matéria (ou cérebro) e a atividade consciente, algo que em nada ajudaria ${ }^{30}$, ou os estados de consciência deveriam ser incluídos na estrutura fisicalista proposta pela ciência. Diante disso, Smart se inclina a aceitar a segunda alternativa, afirmando que todas as

\footnotetext{
29 "It seems to me that science is increasingly giving us a viewpoint whereby organisms are able to be seen as physicochemical mechanisms (...) There does seem to be, so far a science is concerned, nothing in the world but increasingly complex arrangements of physical constituents. All except for one place: in consciousness. That is, for a full description of what is going on in a man you would have to mention not only the physical processes in his tissues, glands, nervous system, and so forth, but also his states of consciousness: his visual, auditory, and tactual sensations, his aches and pains".

30 "Assim, dizer que tais sensações devem estar correlacionadas com processos físicos, não nos ajuda. Pois dizer que elas estão correlacionadas significa dizer que elas são alguma coisa além dos processos físicos" (Smart, 1970a, p. 54).
} 
ocorrências ditas mentais seriam idênticas ocorrências físico-químico no cérebro. Em suas

palavras:

Quando afirmo que uma sensação é um processo cerebral ou que o raio é uma descarga elétrica, estou usando a palavra "é" no sentido estrito de identidade (...) Considere o raio. A ciência física moderna nos diz que o raio é um certo tipo de descarga elétrica que se deve à ionização das nuvens de vapor d'água da atmosfera. Agora sabemos disso, esta é a verdadeira natureza do raio. Notem que não há duas coisas: um flash de luz e uma descarga elétrica. Existe uma só coisa, um flash de luz, que é cientificamente descrito como uma descarga elétrica para a terra que vem de uma nuvem ionizada de moléculas de água. O caso não é, em geral, como aquele de explicar uma pegada por referência ao ladrão. Nós dizemos que o que o raio realmente é, a verdadeira natureza do raio enquanto revelada pela ciência, é uma descarga elétrica (Smart, 1970a, p. 56-57) ${ }^{31}$.

Usando o verbo ser no sentido estrito de identidade (em seu exemplo do flash de luz e da descarga elétrica como sendo o raio), Smart tende a conceber uma manifestação consciente (tal como uma dor de dente, por exemplo) como sendo idêntica a um processo estritamente cerebral.

Entretanto, devemos ressaltar que mesmo assumindo que as sensações são processos cerebrais, o referido autor reconhece que a lógica, ou melhor, o discurso mentalista, característico da descrição e explicação dos fenômenos mentais (particularmente no que se refere às sensações), não é passível de ser reduzido necessariamente ao discurso científico que expressa as descrições e explicações dos fenômenos cerebrais.

\footnotetext{
31 'When a say that a sensation is a brain process or that lightning is an electric discharge, I am using 'is' in the sense of strict identity (...) Consider lightning. Modern physical science tell us that lightning is a certain kind of electrical discharge due to ionization of clouds of water vapor in the atmosphere. This, it is now believed, is what the true nature of lightning is. Note that there are not two things: a flash of lightning and an electrical discharge. There is one thing, a flash of lightning, which is described scientifically as an electrical discharge to the earth from a cloud of ionized water molecules. The case is note at all like that of explaining a footprint by reference to a burglar. We say that what lightning really is, what its true nature as revealed by science is, is an electrical discharge".
} 
Nos termos de Smart:

Sensações não são nada 'além e aquém' de processos cerebrais. Nações não são nada 'além e aquém' de cidadãos, mas isso não mostra que a lógica das sentenças sobre nações seja muito diferente da lógica das sentenças sobre cidadãos; isto também não assegura a tradução das sentenças sobre nações em sentenças sobre cidadãos (Smart, 1970a, p. 56) ${ }^{32}$.

Para Smart, com efeito, os fenômenos mentais e cerebrais, apesar de se referirem ao mesmo tipo de coisas no plano ontológico, encerrariam, cada qual, um tipo de descrição com as propriedades lógicas que lhes são peculiares. Assim, a despeito da "economia ontológica" que a identificação entre os fenômenos mentais e cerebrais pode proporcionar, epistemologicamente, a possibilidade de tradução de noções mentalistas a um discurso científico ou "cerebralista" não estaria assegurada ${ }^{33}$.

Este tipo de materialismo, também conhecido como teoria da identidade, afirma que os eventos mentais e os cerebrais seriam idênticos, não havendo, pois, uma mera correlação entre os eventos. Ou seja, entendendo-se os processos mentais como X e os processos cerebrais como $\mathrm{Y}$, então todas as características atribuídas aos processos mentais (X) podem ser igualmente atribuídas aos processos cerebrais (Y), e vice-versa. De maneira menos abstrata, um determinado tipo de sensação, como por exemplo, a fome que sinto

\footnotetext{
32 'Sensations are nothing 'over and above' brain processes. Nations are nothing 'over and above' citizens, but this does not present in the logic of nation statements being very different from the logic of citizens statements, nor does this ensure the translatability of nation statements in to citizen statements".

${ }^{33} \mathrm{Um}$ autor que se insere numa perspectiva teórica similar à de Smart (sobre a qual discorreremos em maiores detalhes na próxima seção), e que entendemos se pronunciar de maneira mais clara a este respeito seria Place (1970). Assim, de modo geral, podemos dizer que na esteira de Wittgenstein e de Ryle, ou seja, desconfiado de que a maior parte dos problemas filosóficos se deve a confusões no plano da linguagem, Place sugere que a linguagem comum parece encerrar uma dada propriedade que faz com que a diferenciação observada no âmbito dos conceitos implica numa espécie de postulação de entidades distintas (p. 46).
} 
neste exato momento, pode ser entendida como idêntica à ativação de determinados neurônios em meu cérebro responsáveis pela sensação de fome sentida ${ }^{34}$.

Uma outra vertente de materialismo, de caráter mais radical que a teoria da identidade que apresentamos, conhecida como materialismo eliminativista, afirma que o desenvolvimento progressivo das neurociências aponta para a perspectiva de que a compreensão do funcionamento do cérebro faria com que o vocabulário mentalista característico da psicologia popular (folk psychology) desaparecesse, sendo substituído por uma teoria científica da mente, articulada num vocabulário propício a expressar adequadamente os conhecimentos cerebrais.

Para Churchland (2004), um dos expoentes dessa vertente, expressões do tipo: crenças, desejos, sensações, dentre outras, que expressam noções "obscuras” da psicologia popular, desapareceriam completamente quando desvendássemos o modo de funcionamento do cérebro, descrevendo-o em termos absolutamente científicos ${ }^{35}$.

O eliminativismo proposto por Churchland pode ser concebido, de modo geral, como uma radicalização das teorias reducionistas, bem como das teorias da identidade. Sendo assim, vejamos quais seriam as diferenças entre as noções de redução e eliminação, contrapondo-as com o que vimos acerca das teorias da identidade.

\footnotetext{
${ }^{34}$ Note, mais uma vez, que apesar da correspondência no estabelecimento de identidades entre mente e cérebro no plano ontológico, Smart entende que no âmbito discursivo, haveria certa autonomia entre o mental e o cerebral. Retomaremos este ponto na próxima seção ao discutirmos as críticas dirigidas a Smart.

35 Uma analogia recorrente dos materialistas eliminativistas seria de que a psicologia contemporânea equivaleria à antiga teoria do flogisto, que, para explicar os fenômenos da combustão da madeira e da ferrugem do ferro, por exemplo, postulavam o desprendimento de uma substância (o flogisto) de tais materiais. Posteriormente, descobriu-se que na ocorrência de tais fenômenos, substância alguma era eliminada, mas, pelo contrário, uma outra substância era assimilada, a saber, o oxigênio. Assim, com a descoberta do oxigênio e com a compreensão de algumas de suas propriedades mais relevantes, a teoria do flogisto pôde ser posta de lado, de modo que os fenômenos relativos à combustão e oxidação passaram a ser explicados por meio de outro construto teórico constituído por novas categorias.
} 
Devido às diversas maneiras de se conceber a noção de redução, podemos dizer que, de modo geral, enquanto as teorias da identidade (que como vimos) afirmam que estados mentais seriam, de fato, estados cerebrais ${ }^{36}$, as teorias reducionistas afirmam que estados mentais poderiam ser reduzidos a estados cerebrais, de modo que o percurso de uma posição reducionista ficaria mais ou menos assim: psicologia $\rightarrow$ biologia $\rightarrow$ química $\rightarrow$ física. Sem pretendermos aprofundar o assunto, e tendo em vista somente o propósito de evitar que a noção de redução não seja demasiado abstrata, vejamos as linhas gerais de um modo particular de se conceber a redução interteórica, tal como analisada por Nagel .

Nagel (1979), afirma que existem dois tipos de redução, a saber, redução homogênea e redução heterogênea. No primeiro caso, da redução homogênea, a teoria que se quer reduzir (T1) tem seus conceitos expressos de maneira inalterada por uma teoria mais abrangente (T2), de modo que o que era antes explicado em T1 passa a ser explicado nos termos da nova teoria mais abrangente. $\mathrm{O}$ exemplo clássico desse tipo de redução teórica seria o da redução das leis do movimento terrestre ou sub-lunar de Galileu às leis gerais do movimento de Newton, que, utilizando-se de praticamente os mesmos termos de Galileu, passou a explicar não apenas os movimentos terrestres, mas também o movimento das estrelas e planetas.

No caso da redução heterogênea, por sua vez, os fenômenos explicados por T1 passam a ser explicados por uma teoria (T2), que, originalmente, não se propõe a explicar os mesmos tipos de fenômenos que T1 explica. Assim, pelo fato de T2 não utilizar os mesmos conceitos que $\mathrm{T} 1$, necessário se faz que regras de correspondência ou leis-ponte (bridge laws) entre os termos e assunções de $\mathrm{T} 1$ e $\mathrm{T} 2$ sejam elaboradas, para que se possa efetuar esse tipo de redução. Um exemplo recorrente de redução heterogênea encontrada na

\footnotetext{
${ }^{36}$ Respeitando-se o vocabulário da psicologia popular.
} 
literatura sobre o assunto seria a redução da termodinâmica à mecânica estatística, sendo que os fenômenos térmicos passam a ser explicados em termos de regularidades estatísticas verificadas na interação mecânica entre partículas.

Objeções às concepções de redução, particularmente a esta distinção caracterizada por Nagel, são muitas. Em geral, elas giram ao redor de considerações críticas acerca dos exemplos tomados da história da ciência como modelos deste ou daquele tipo de redução defendida; bem como fazem menção a problemas de ordem epistemológica subjacentes à própria condição de possibilidade de redução interteórica. Mas enfim, com tal discussão pretendemos apenas pôr em evidencia que por trás da noção de redução se assenta a premissa de que a descrição da realidade promovida pela teoria mais abrangente (T2) (e que teria a física como modelo), seria uma descrição mais completa, econômica ${ }^{37}$ e privilegiada da realidade, que entenderia as descrições fornecidas pela psicologia, biologia e química, como meras variações da descrição do mundo físico.

$\mathrm{Na}$ perspectiva reducionista, pois, a realidade dos fenômenos mentais ou psicológicos não é questionada. O reducionista, em resumo, parte da existência da mente, afirmando que as explicações dos fenômenos mentais seriam passíveis de serem reduzidos às explicações referentes aos fenômenos físicos. Assim, observa-se que (pelo menos na perspectiva de Nagel, que vagamente delineamos) a redução interteórica é concebida em termos de uma relação estritamente lógica entre conceitos e expressões de teorias, visando fundamentalmente a unificação explicativa, podendo, em conseqüência, dar ensejo para se pensar numa espécie de simplificação ontológica.

\footnotetext{
${ }^{37}$ Econômica, no sentido de que toda a variedade metodológica e conceitual das teorias reduzidas se resumiriam apenas às leis de uma física unificada.
} 
Feitos esses apontamentos sobre a proposta da teoria da identidade proposta por Smart, bem como sobre as linhas gerais do projeto reducionista (ilustrada mediante a concepção de redução descrita por Nagel), podemos retomar à discussão sobre a proposta eliminativista ressaltando que, para estes, a legitimidade que os reducionistas conferem às teorias passíveis de serem reduzidas deveria ser colocada em questão.

Para Churchland (2004), com efeito, as teorias não científicas acerca do comportamento humano (psicologia popular), com que descrevemos crenças, desejos, temores, sensações, etc., seriam um conjunto de teorias ou crenças incorretas que não poderiam ser reduzidas a nenhuma outra teoria, mas deveriam ser simplesmente eliminadas e substituídas por uma teoria neurocientífica madura e acabada.

Numa longa, porém, esclarecedora passagem, eis como Churchland sintetiza o que apresentamos acerca da postura eliminativista enquanto programa de pesquisa distinto dos programas reducionistas:

Para os materialistas eliminativistas, as correspondências um-a-um não serão encontradas, e a estrutura psicológica de nosso senso comum não pode obter uma redução interteórica, porque a estrutura psicológica de nosso senso comum é uma concepção falsa e radicalmente enganosa das causas do comportamento humano e da natureza da atividade cognitiva. Desse ponto de vista, a psicologia popular não é apenas uma representação incompleta de nossa natureza interior; ela é pura e simplesmente uma representação distorcida de nossas atividades e estados internos. Conseqüentemente, não podemos esperar que uma explicação realmente adequada de nossa vida interior feita pela neurociência revele categorias teóricas que correspondam exatamente às categorias do arcabouço de nosso senso comum. Dessa forma, devemos esperar que o antigo arcabouço seja simplesmente eliminado, e não reduzido, por uma neurociência amadurecida. (Churchland, 2004, p. 79).

Para os eliminativistas, a estrutura psicológica de nosso senso comum, por ser completamente errônea, não pode ser reduzida mediante correspondências neurológicas 'um-a-um' como desejam os reducionistas, mas ela deve ser pura e simplesmente eliminada, dando lugar ao arcabouço de uma neurociência amadurecida. 
Um aspecto de extrema importância acerca do eliminativismo versa sobre a idéia de que não estaria descartada a possibilidade de que uma teoria psicológica consistente, radicalmente distinta da psicologia popular, pudesse ser desenvolvida paralelamente à madura teoria neurocientífica. Entretanto, tal teoria psicológica deve possuir um caráter radicalmente distinto da psicologia popular, no sentido de fornecer descrições, explicações e predições de fenômenos mentais de maneira fundamentalmente científica.

Tendo em vista o que apresentamos acerca do eliminativismo, poder-se-ia formular a seguinte questão: já que o eliminativismo assenta-se na premissa de que a psicologia popular seria completamente equivocada, resta saber o porquê de tal asserção, ou devemos ignorar o fato de que ela vem sendo utilizada com relativo sucesso por um considerável período de tempo $?^{38}$

Ciente de tais questionamentos, Churchland dirá que existem pelo menos três motivos que o levam a rejeitar a plausibilidade da psicologia popular. O primeiro deles é o seu fiasco em termos de explicação, predição e manipulação no que se refere aos eventos mentais, sobretudo quando se pensa na relação entre danos cerebrais e "desvios" ou particularidades comportamentais. De acordo com o autor: "Quando examinamos as muitas e desconcertantes deficiências comportamentais e cognitivas de que sofrem as pessoas com danos cerebrais, nossos recursos explicativos e descritivos começam a tatear no vazio" (Churchland, 2004, p. 83-4).

O segundo motivo baseia-se na idéia de que a psicologia popular só vigora ainda em razão da complexidade dos fenômenos que aborda: 
A psicologia popular, ao que parece, sobreviveu por tanto tempo não porque estivesse basicamente correta em suas representações, mas porque os fenômenos que ela examina são tão terrivelmente difíceis que qualquer abordagem útil deles, não importa o quão precária, dificilmente seria descartada sem mais (idem, p. 84).

O terceiro motivo indicado por Churchland para rejeitar a psicologia popular se articula como um argumento contra as teorias da identidade e o reducionismo, na medida em que o autor afirma que a dificuldade de redução da psicologia popular corrobora a idéia de que ela seria, de fato, uma teoria fundamentalmente errônea:

O eliminativista irá salientar que as exigências de uma redução são bastante rigorosas. A nova teoria deve implicar um conjunto de princípios e conceitos incorporados, que espelhem de uma maneira bastante precisa o arcabouço conceitual específico a ser reduzido. $\mathrm{O}$ fato é que existem muitos mais modos de ser uma neurociência bem sucedida em termos de explicações, sem, ao mesmo tempo, espelhar o arcabouço da psicologia popular, do que existem modos de ser uma neurociência bem sucedida em termos de explicação e, ao mesmo tempo, espelhar o arcabouço conceitual específico da psicologia popular. Assim, a probabilidade a priori do materialismo eliminativista não é menor, mas sim, substancialmente maior que a de ambas as teorias adversárias (ibidem, p. 85).

Em outras palavras, este último motivo salientado por Churchland, acerca do rigor de uma redução bem sucedida, o leva a considerar (a priori) o eliminativismo como um programa de pesquisa mais plausível que as teorias da identidade e o reducionismo. Isso porque, para Churchland, os critérios de uma redução interteórica são bastante rigorosos pelas razões observadas na citação que precede.

Em resumo, os motivos que levam Churchland a entender que a psicologia popular seria equivocada e que deveria ser eliminada seriam os seguintes: a) ela encerra sérias limitações em termos explicativos, bem como nas predições e manipulações relativas aos

\footnotetext{
38 Destacamos a expressão "relativo sucesso" em razão de que, apesar de certos casos problemáticos, tais como a dificuldade que pessoas com sinestesia enfrentam para se fazer entender, por exemplo, ainda assim, em geral, as pessoas se comunicam, ou pelo menos agem como se se comunicassem umas com as outras.
} 
fenômenos mentais; b) a psicologia popular só vigora em razão da complexidade dos fenômenos que aborda, de modo que, independentemente de sua precariedade em tratar dos fenômenos relativos à mente, não poderia ser descartada em virtude de não haver teorias melhores para substituí-la e; c) a rejeição da possibilidade de redução que, segundo Churchland, deve satisfazer critérios rigorosos.

Um outro ponto a ser ressaltado sobre o materialismo eliminativo de Churchland diz respeito ao porquê de sua esperança de que uma neurociência madura venha a proporcionar um melhor entendimento dos fenômenos relativos à mente e conseqüente eliminação da psicologia popular.

Um dos princípios do qual Churchland parte consiste em sua adesão incondicional à tese de que toda observação se daria no contexto de um determinado arcabouço teóricoconceitual, sendo que os juízos pautados na observação expressariam a qualidade do arcabouço que os permeiam: "O fato é que toda observação ocorre no contexto de um sistema de conceitos e que nossos juízos observacionais são apenas tão bons quanto o arcabouço conceitual no qual eles são emitidos" (Churchland, 2004, p. 86).

Nesta perspectiva, reiterando o que já apresentamos, tratando-se o arcabouço conceitual da psicologia popular de algo, para Churchland, equivocado, os juízos pertencentes a folk psicology seriam, para dizer o mínimo, de "baixíssima qualidade", o que tornaria desejável que descrições, explicações e predições no contexto de outro arcabouço teórico fossem estabelecidas (no caso, o de uma neurociência evoluída).

Se isso se desse, ou seja, caso o construto teórico de uma neurociência madura se estabelecesse, entende o autor que uma significativa ampliação de nossa capacidade de observar, descrever, explicar e prever fenômenos mentais ocorreria; e o que é mais importante: nosso poder de introspecção se expandiria de maneira fantástica. Em suas 
palavras:

Quando a neurociência tiver amadurecido, a ponto de a pobreza de nossas atuais concepções ter-se tornado manifesta a todos, e a superioridade do novo arcabouço tiver sido estabelecida, poderemos, por fim, dar início à tarefa de reformular nossas concepções das atividades e estados internos, no interior de um arcabouço conceitual realmente adequado. Nossas explicações sobre o comportamento uns dos outros irão recorrer a coisas como nossos estados neurofarmacológicos, nossa atividade neural em áreas anatômicas específicas e a outros estados que forem relevantes para a nova teoria. Nossa introspecção individual também será transformada e poderá ser profundamente aprimorada em razão de um arcabouço conceitual mais penetrante e preciso, com o qual ela terá de trabalhar - da mesma forma que a percepção do céu noturno pelo astrônomo foi em muito aprimorada pelo conhecimento detalhado da moderna teoria astronômica de que dispõe (Churchland, 2004, p. 81-82).

Esta possibilidade de enriquecimento de nossa capacidade discriminativa mediante introspecção, que, segundo Churchland, o eliminativismo encerra, poderia fazer com que o problema epistemológico da relação mente-corpo se dissolvesse, dando ensejo para que a objetivação das sensações ou instauração de uma "fenomenologia objetiva" ocorresse. Isso porque, segundo o autor, o refinamento teórico-conceitual proporcionaria a dissipação das tais assimetrias mencionadas anteriormente.

São bem conhecidos na literatura acerca do tema casos em que músicos experientes, bem como sommeliers de diversas modalidades, apresentam um poder discriminatório muito superior ao de não especialistas, podendo ouvir ou discernir, pelos sentidos, nuances que escapam aos não especialistas.

Comentando tais casos aventados acima (sobre o poder sensorial e discriminatório de músicos, sommeliers, além de astrônomos) Churchland diz o seguinte:

Em cada um desses casos, o que é por fim dominado é um arcabouço conceitual - musical, químico ou astronômico - um arcabouço que incorpora muito mais sabedoria sobre o domínio sensorial em questão do que podemos imediatamente perceber por meio de nossa capacidade de discriminação não apoiada por algum tipo de treinamento. Esses arcabouços são, em geral, uma herança cultural: são montados no decorrer de muitas gerações, e seu domínio oferece a nossas vidas sensoriais uma riqueza e penetração que seriam impossíveis em sua ausência (Churchland, 2004, p. 276, grifo nosso). 
Da citação que precede, interessa atentar para a idéia de que para que haja a expansão da capacidade de sentir e discriminar determinados tipos de sensações, não basta apenas tomar conhecimento de certas informações (geralmente herdadas culturalmente) do tipo: a cachaça $\mathrm{X}$ do ano y, envelhecida em tonel de carvalho de 200 litros, mediante consenso de uma junta de 30 sommeliers obteve no quesito adstringência o veredicto $\mathrm{Z}$. Pois para que ocorra o desenvolvimento do poder de percepção e apuramento verbal (seguindo o exemplo acima) é preciso que se experimente vários tipos de cachaça, em circunstancias das mais variadas possíveis; e que se estude os relatos orais e escritos acerca do tema; enfim, é preciso articular finamente determinados conceitos à experiência propriamente dita. 


\section{2 - As limitações do materialismo}

Feita na seção precedente uma breve exposição de duas tendências materialistas que buscam compreender a natureza doas estados mentais e determinar seu lugar na natureza, passemos a analisar, num primeiro momento, algumas críticas dirigidas, em particular, às idéias de Smart e Churchland, e, num segundo momento, a avaliar objeções de caráter mais abrangente que podem ser dirigidas ao materialismo em filosofia da mente de modo geral.

Quanto à teoria da identidade proposta por Smart, devemos ressaltar que, em geral, as críticas giram ao redor da idéia de que ao tentar identificar os processos mentais aos cerebrais, incorre-se inevitavelmente em equívocos lógico-linguísticos. A aplicação da lei de Leibniz da indistinguibilidade dos idênticos - que afirma que em caso de dois termos se referirem ao mesmo objeto (mente e cérebro, por exemplo), então tudo o que se diz sobre um dos termos pode ser dito acerca do outro ${ }^{39}$ - seria o recurso mais utilizado por parte dos críticos de tal teoria da identidade. Assim, no caso da identidade mente-cérebro proposta por Smart, a lei de Leibniz seria violada, pois haveria propriedades mentais que não seriam encontradas no cérebro (e vice-versa), tais como a não espacialidade da mente, por exemplo.

Ainda de acordo com aqueles que entendem que a teoria da identidade tal como Smart a propõe viola a lei de Leibniz da indistinguibilidade dos idênticos poder-se-ia dar o exemplo de uma outra propriedade mental que aparentemente não faria sentido ser atribuída

\footnotetext{
39 "É necessário sempre que, além da diferença do tempo e do lugar, haja um princípio interno de distinção; e embora haja várias coisas da mesma espécie, é todavia verdade que jamais existem coisas inteiramente semelhantes; assim, se bem que o tempo e o lugar (isto é, a relação ao que está fora) nos sirvam para distinguir as coisas que não distinguimos bem por si mesmas, as coisas não deixam de ser distinguíveis em si. O específico da identidade e da diversidade não consiste, por conseguinte, no tempo e no lugar, embora seja verdade que a diversidade das coisas é acompanhada pela do tempo ou do lugar, visto que acarretam com elas impressões diferentes sobre as coisas" (Leibniz, 1996, livro II, cap. XXVII).
} 
ao cérebro, que seria a dimensão significativa que caracteriza as crenças, por exemplo. Como aventamos (seção 1.3), as crenças possuem um conteúdo proposicional específico, ou seja, podem ser verdadeiras ou falsas bem como desempenhar funções lógicas diversas. Exemplificando, parece não fazer muito sentido afirmar que as células nervosas da segunda camada de meu córtex pré-frontal orbital signifiquem alguma coisa, como por exemplo, o raciocínio aritmético que agora faço de cabeça relativo à compra de verduras na feira.

Uma possibilidade de réplica por parte dos adeptos da teoria da identidade poderia ser a de tentar convencer os críticos de que a estranheza causada pelo emprego do vocabulário cerebralista (como no exemplo apresentado acima) tem de ser superada porque a ciência estaria repleta de explicações que invariavelmente desafiam nossa capacidade de compatibilizar tais explicações com nossas concepções de senso comum. Como observa Churchland (2004), comentando tal réplica por parte daqueles que endossam a teoria da identidade:

O 'abuso' com relação aos modos de falar aceitos, muitas vezes, é uma característica essencial do progresso cientifico real! Talvez tenhamos simplesmente de nos acostumar com a idéia de que os estados mentais têm localização anatômica e de que os estados do cérebro têm propriedades semânticas (Churchland, 2004, p. 60).

Ademais, como pudemos observar na seção precedente, Smart não advoga a exclusividade de uma lógica específica no plano descritivo da realidade, de modo que nossa descrição usual acerca da mente (realizada por meio de uma lógica e conceitos mentalista) não precisa ser necessariamente descartada, podendo conviver com um linguajar técnico de cunho cerebralista 
Uma outra possibilidade de contornar as críticas às teorias da identidade que se utilizam da aplicação da lei de Leibniz da indistinguibilidade dos idênticos seria oferecida por Place (1970). No artigo Is consciousness a brain process?, resumidamente, o referido autor sugere que nas teorias da identidade o verbo ser não deve se tomado como uma definição a priori do tipo "a raíz quadrada de quatro é dois", mas sim como uma palavra que designe a possibilidade de confirmação empírica a posteriori, como por exemplo "a linguagem humana está intimamente relacionada às sinapses que se passam na área de Broca”. Em suas palavras:

\begin{abstract}
A distinção que aqui tenho em mente é a diferença de função da palavra 'é' em declarações como 'um quadrado é um retângulo eqüilátero', 'vermelho é uma cor', 'para entender uma instrução é preciso que se aja apropriadamente sob circunstancias apropriadas', e sua função em declarações como 'esta mesa é um velho caixote', 'o chapéu dela é uma trouxa de palha ligada com uma corda', 'uma nuvem é uma massa de água que cai com outras partículas em suspensão' (...) Declarações como 'um quadrado é um retângulo eqüilátero' são declarações necessárias que são verdades por definição. Declarações como 'esta mesa é um velho caixote', de outro modo, são declarações contingentes que tem de ser verificadas pela observação (Place, 1970, p. 44) ${ }^{40}$.
\end{abstract}

Deste modo, o caráter de necessidade envolvido em toda definição exclusiva seria evitado, dando ensejo à teoria da identidade mente-cérebro se consolidar como um programa de pesquisa científico passível de ser desenvolvido.

Somando-se os questionamentos de caráter lógico relacionados à aplicação da lei de Leibniz haveria também o problema da opacidade da referência no que tange ao estabelecimento de identidades. Como aventamos na terceira seção do primeiro capítulo, estados mentais podem ser concebidos em pelo menos duas perspectivas, quais sejam:

\footnotetext{
40 "The distinction I have in mind here is the difference between the function of the Word 'is' in statements like 'a square is an equilateral rectangle', 'red is a color', 'to understanding an instruction is to be able to act appropriately under the appropriate circumstances', and its function in statements like 'his table is an old packing-case', 'her hat is a bundle of straw tied together with string', 'a cloud is a mass of water droplets or other particles in suspension' (...) Statements like 'a square is an equilateral rectangle', are necessary
} 
estados qualitativos e atitudes proposicionais. No que se refere a esta última, podemos dizer que no contexto da filosofia da linguagem e da mente (em especial, no final do século XIX e primeira metade do século XX) o estudo sistemático das atitudes proposicionais revelou que estas podem causar o que denominamos "opacidade da referência”. Expliquemos:

Na obra Lógica e filosofia da linguagem (1978), em especial no segundo capítulo intitulado "Sobre o sentido e a referência", Frege, resumidamente, observa que a igualdade de referência não pressupõe necessariamente a igualdade de sentidos. Assim, por meio de alguns exemplos como o da "estrela da manhã" e a "estrela da tarde" - que teriam dois sentidos diferentes que se referem ao mesmo objeto, que, no caso, é o planeta Vênus Frege conclui que a igualdade de referência não exige a igualdade de sentido, de modo que uma pessoa poderia perfeitamente se referir ao planeta Vênus apenas como estrela da manhã, ignorando que a estrela da tarde também referir-se-ia ao planeta Vênus, e viceversa. Analogamente, no contexto da identidade mente/cérebro tal como Smart advoga, poderia ocorrer que um determinado estado mental correspondesse a estados cerebrais diferentes, ou seja, um mesmo estado mental corresponder a diversos arranjos neuronais.

Deve-se ter em mente que tal objeção só valeria contra a teoria da identidade proposta por Smart, em que um dado estado mental ou um token é idêntico a um estado cerebral particular. Porém, no caso da evolução da teoria da identidade entre pontos específicos para a teoria da identidade entre tipos ou generalidade de tokens (onde o que vale é a identificação entre um estado mental e um estado cerebral, não importando nenhuma especificidade no estabelecimento das identidades), a objeção da opacidade da referência não se aplicaria. Isso porque no estabelecimento entre identidades de tipos, um

statements which are true by definition. Statements like 'his table is an old packing-case', on the other hand, are contingents statements which have to be verified by observation". 
estado mental pode se dar em organizações cerebrais diferentes, como sugere Bechtel: “(a) Toda vez que me encontro num determinado estado mental particular, este estado mental é idêntico a um estado cerebral, mas (b) em outras ocasiões, quando me encontro no mesmo estado mental, posso ter um estado cerebral diferente" (Bechtel, 1988, apud Gonzales, 1996).

Como Putnam (1960) ressalta, a teoria da identidade tal como Smart a concebe, servia muito bem para explicar cada token ou ocorrência específica de evento mental, mas necessitava de corretivos, ou uma melhor articulação para ser capaz de abranger os tipos (ou generalidade dos tokens) desses eventos. Em outros termos, uma específica dor de barriga pode ser concebida como um especial estado do cérebro, mas a dor de barriga entendida de modo geral deve ser entendida em termos de "papéis funcionais" descritos por determinadas relações causais. Como veremos adiante, especialmente no terceiro capítulo, assim surge o funcionalismo, que pode ser concebido como uma espécie de evolução da teoria da identidade apresentada na seção precedente.

Apresentadas algumas objeções de teor lógico à teoria da identidade de Smart, bem como algumas réplicas que possivelmente contornam tais críticas, e, como sinalizamos nas linhas acima, delineada a perspectiva que se seguiu à teoria da identidade, passemos a analisar as objeções dirigidas ao materialismo eliminativista, tal qual proposto por P. M. Churchland.

Uma primeira diz respeito à possibilidade de que a esperança de tal programa de pesquisa não se concretize, qual seja, o programa de que o desenvolvimento das neurociências culmine na instauração de uma ciência do cérebro madura capaz de proporcionar o abandono da psicologia popular. Dizemos isso em virtude de entendermos que tal projeto se apóia em bases um tanto frágeis, que consistem meramente na esperança 
de que a psicologia popular possa ser eliminada e substituída por uma neurociência futura, daí nossa asserção de que a negação de tal esperança possa ser entendida como objeção.

Uma segunda objeção seria a de que contemporaneamente, em certos exames de neuro-imagem e em determinadas técnicas cirúrgicas cerebrais, são cada vez mais importantes os relatos "convencionais" ou em linguagem comum do próprio paciente submetido a tais exames ou intervenções cirúrgicas. Ou seja, o desenvolvimento da neurociência tão almejado pelo eliminativista, num certo sentido, caminha para um estreitamento cada vez maior com o discurso comum que expressa noções "obscuras" da psicologia popular, em vez de promover o abandono desta. Isso sugere que talvez não sejam assim tão disparatadas as noções da psicologia popular.

Uma terceira objeção, que, na verdade seria um complemento da anterior, colocaria em questão a asserção de que as noções da psicologia popular seriam completamente disparatadas na descrição dos processos mentais, pois afinal de contas, em seus afazeres cotidianos, pelo menos, as pessoas se comunicam: ou será, prossegue o argumento, que em termos pragmáticos haveria muitos problemas em dizer, por exemplo, que se está satisfeito (ou seja, que não mais se deseja comer) após uma refeição? Além disso, não se pode negligenciar que há milhares de anos a linguagem ordinária (especialmente no que se refere a noções mentalistas) vem cumprindo, relativamente bem seu papel.

Uma quarta objeção ao eliminativismo questiona a radicalidade do projeto eliminativista, pois afinal, seria perfeitamente possível que mesmo que surja uma poderosa teoria do cérebro, uma eliminação completa do vocabulário mentalista poderia não ocorrer, de modo que em vez de ser pura e simplesmente eliminado, o vocabulário mentalista pudesse ser reduzido. Tal objeção, a rigor, o próprio Churchland reconhece como boa objeção, e defende-se tentando minimizar a radicalidade de seu projeto: 
Talvez essa queixa seja justa. Como quer que seja, ela sem dúvida ressalta o fato importante de que não estamos aqui contrapondo duas possibilidades simples e mutuamente excludentes: a redução pura e simples contra a eliminação pura e simples. Ao contrário, essas duas posições são os dois extremos de uma gama gradual de resultados possíveis, entre os quais ocorrem casos mistos de eliminação parcial e redução parcial (Churchland, 2004, p.88).

Ou seja, na passagem acima, Churchland minimiza a radicalidade de seu projeto afirmando que pode ser que haja uma espécie de caso misto de eliminação e redução parciais.

Uma última objeção (5) diz respeito às dificuldades ou até mesmo impossibilidade do materialismo eliminativo ser capaz de reduzir a um discurso objetivo, de terceira pessoa, os aspectos qualitativos experimentados subjetivamente e expressos num discurso de primeira pessoa. Como dissemos, Chalmers (1996) ressalta que o que faz com que o problema da experiência pareça intratável é a idéia de que ela não poderia ser explicada em termos de mecanismos neurais e/ou computacionais. Num discurso científico, de cunho neurofisiológico, por exemplo, a distinção entre sono e vigília demandaria somente uma explicação em termos de mecanismos neurofisiológicos subjacentes a tais estados contrastantes, o que seria o suficiente para a compreensão de tais estados. Porém, a riqueza da experiência que acompanha o estado de vigília bem como os sonhos mais vívidos parecem escapar a tais explicações. Em outras palavras, o que está em questão é o problema da tradução ou abismo explicativo, tal como levantado por Levine, que tratamos na terceira seção do primeiro capítulo.

Em relação a essa última objeção (que, a rigor, sintetizaria a perspectiva por nós escolhida no presente trabalho para abordar a relação mente-corpo), que também pode ser dirigida às teorias da identidade, bem como contra o funcionalismo, pode-se dizer, seria o 
grande desafio a ser superado pela filosofia da mente e ciência cognitiva. Mas antes de enfrentarmos essa questão, devemos explorar mais detalhadamente o terreno, avaliando anteriormente a perspectiva funcionalista da mente, em especial, a posição de Shoemaker (1980), que entende não haver grandes problemas em lidar com a questão resumida acima.

Mas antes de passarmos ao próximo capítulo, em que apresentaremos o funcionalismo e analisaremos o modo desta lidar com a relação mente-corpo, bem como discorrer sobre a posição de Shoemaker, recapitulemos brevemente as objeções dirigidas nessa seção ao materialismo eliminativista, e apresentemos uma última objeção que pode ser dirigida ao materialismo de modo geral.

Recapitulando, pudemos observar que aqueles que se empenham no programa de pesquisa eliminativista devem resolver, pelo menos, as questões arroladas acima (dentre outras possíveis), quais sejam: (1) o reforço da sustentabilidade do materialismo eliminativista como um legítimo programa de pesquisa, ou seja, eles deveriam se basear em algo mais substancial e menos ingênuo que a mera esperança de que uma neurociência madura culmine na elucidação do mental tornando possível a eliminação da psicologia popular; (2) a resolução do paradoxo de ser um programa que se baseia na crença de que o desenvolvimento da neurociência culmine na eliminação da psicologia popular, quando, de fato, o que se observa no desenvolvimento neurocientífico real é um estreitamento (para não dizer dependência) cada vez maior entre a neurociência e os relatos proferidos em "linguagem comum", ou melhor, a linguagem usual expressa em noções mentalistas, características da psicologia popular; (3) o problema da radicalidade do projeto eliminativista, de modo que a eliminação completa do vocabulário mentalista poderia não ocorrer; e, finalmente (4) a dificuldade (senão impossibilidade) do eliminativismo elucidar os aspectos qualitativos da experiência consciente. 
Além dessas críticas um tanto "desgastadas" de concepção e explicação dos fenômenos mentais apresentadas, gostaríamos de chamar a atenção para uma posição crítica que pode ser estendida a todo o projeto materialista e que se articula como, no mínimo, uma advertência à adoção do naturalismo como postura filosófica.

Nos dias correntes, pelo menos no que tange ao contexto da ciência cognitiva no qual entendemos se inserir a filosofia da mente, toda asserção como a proferida na última linha do parágrafo acima - qual seja, uma asserção de que se pretende criticar o naturalismo - causa certa perplexidade; isso porque grande parte daqueles que pensam questões relativas à mente, hoje em dia, compactuam com uma vertente ou outra de naturalismo. Assim, necessário se faz que esclarecimentos sejam feitos sobre o que exatamente entendemos por naturalismo, e, como sinalizamos nas linhas acima, a qual vertente pretende-se objetar.

Como Goldman (1998) ressalta, o naturalismo é uma postura filosófica de caráter muito geral, de modo que fornecer uma definição específica e definitiva de tal posição seria bastante difícil. No mesmo sentido, Sellars (1922), por exemplo, ressalta:

\begin{abstract}
Nós somos (agora) todos naturalistas. Mas, mesmo assim, esse naturalismo comum é de uma espécie muito vaga e geral, capaz de cobrir uma diversidade imensa de opiniões. É muito mais a admissão de uma direção de que uma crença claramente formulada. É menos um sistema filosófico que um reconhecimento das implicações impressionantes das ciências físicas e biológicas. E, para não ficar ultrapassada, a psicologia juntou-se ao coro (apud Kornblith, 1998, p. 148).
\end{abstract}

Mas independentemente de uma caracterização precisa e esquemática de todas as direções que o naturalismo possa assumir, observa-se a tendência geral de que a

\footnotetext{
${ }^{41}$ Por conta da vasta literatura impressa (principalmente de introdução à ciência cognitiva e filosofia da
} 
investigação filosófica deva estar em sintonia com os resultados empíricos e orientações metodológicas das ciências particulares, em especial, das ciências mais básicas (física, química, biologia) ${ }^{42}$.

No que tange às investigações metafísicas de orientação naturalista, eis como Kornblith (1998) explicita sua opinião, a qual entendemos resumir uma tendência bem difundida entre os filósofos naturalistas:

Eu creio que em metafísica nós devemos seguir as sugestões de nossas melhores teorias científicas disponíveis. Como bem colocou Wilfrid Sellars: "... a ciência é a medida de todas as coisas, do que é que assim seja, e do que é que não seja" [Sellars, 1963, p. 173]. As atuais teorias científicas são ricas em suas implicações metafísicas. A tarefa do metafísico naturalista, como vejo, é simplesmente extrair as implicações metafísicas da ciência contemporânea (...). Para o naturalista, simplesmente não há rota extracientífica para a compreensão metafísica (p.149).

Dada esta caracterização bastante geral do naturalismo, e, atentando para a perspectiva de se pensar em questões metafísicas sob um viés naturalista, tal como Kornblith a concebe, percebe-se que as posturas materialistas apresentadas na seção precedente compartilham a idéia de que para se determinar o locus da mente, deve-se ter como base as implicações metafísicas (e, acrescentemos, metodológicas) das atuais teorias científicas. Ou melhor: as posturas materialistas apresentadas se fiam ou na esperança de que as correspondências, ou identidades entre aspectos mentais e cerebrais (no caso das teorias da identidade) serão esclarecidas com o desenvolvimento das ciências do cérebro, ou na hipótese ainda mais radical, de que o desenvolvimento das neurociências permitirá

mente) acerca de tais críticas às teorias da identidade e do materialismo eliminativista.

${ }^{42}$ Sobre a perspectiva de "comunhão" da filosofia com as ciências mais básicas (em especial a física), pode-se dizer que tal comunhão verifica-se, sobretudo, no que diz respeito às investigações metafísicas de caráter naturalista onde predominam investigações acerca do tipo de coisas existentes no mundo (discorreremos melhor sobre este ponto adiante). Já no caso de se pensar numa epistemologia naturalista, o modelo de ciência preponderante seria a psicologia, como bem ilustra o trabalho de Quine, só para citar um exemplo bem conhecido. Mas além da psicologia como modelo diretriz das investigações epistemológicas de orientação naturalista, pode-se pensar na sociologia, dentre outras disciplinas humanísticas como modelo, sobretudo, na 
que o vocabulário da psicologia popular seja eliminado e substituído por uma psicologia científica ou neuropsicologia (o que abre precedentes para que, como vimos, uma simplificação ontológica possa se dar).

É claro que uma orientação filosófica de caráter naturalista e teor materialista não está necessariamente comprometida com uma economia ou "enxugamento" nos planos ontológico e descritivo da realidade mediante a identificação entre "espécies de coisas" ou eliminações de um determinado vocabulário, como querem os eliminativistas, por exemplo (apesar de ser esta a tendência geral [de economia]). Mas a afirmação amplamente aceita por parte dos materialistas é a de que no plano ontológico, a constituição da realidade é essencialmente física. "Eu considero o materialismo como a visão de que todas as coisas são inteiramente constituídas pelo físico; a ciência atual não nos dá nenhuma razão para duvidar desta tese" (Kornblith, 1998, p. 152-153) ${ }^{43}$.

Mas se é mesmo assim, ou seja, já que a ciência atual não nos deixa dúvidas de que todas as coisas são constituídas por entidades materiais, o que quererão dizer afinal os físicos contemporâneos ao utilizar o termo físico ou material? Ou devemos pressupor que apenas o mental necessita de uma caracterização satisfatória?

Na edição de agosto de 2002 da Scientific American Brasil, Caraveo e Roncadelli (em matéria de capa) relatam que é consenso entre os físicos contemporâneos que cerca de 90\% da matéria existente no universo continua a escapar às observações, de modo que não se sabe qual seria sua constituição, tampouco suas propriedades fundamentais ${ }^{44}$. Sem

perspectiva epistemológica "historicista", largamente explorada a partir da segunda metade do século XX, que reconhece nos trabalhos de Kuhn um exemplo paradigmático.

${ }^{43}$ Lembremos, porém, que tal fisicalismo também incorpora teses oriundas da biologia, tal como a seleção natural.

44 "Se pensarmos que o estudo do cosmo por meio da radioastronomia, óptica, raios X e gama pode nos fornecer um quadro completo do nosso universo estaremos cometendo um erro grosseiro. Há décadas sabemos que a matéria luminosa - aquela que "vemos" porque emite radiação eletromagnética, ou seja, luz, 
pretendermos entrar em detalhes mais técnicos sobre os problemas existentes na comunidade dos físicos sobre a concepção de matéria, assumamos somente a afirmação genérica de que não se sabe ao certo o que seja de fato pelo menos $90 \%$ da matéria constitutiva do universo, de modo que "agora descobrimos que somos feitos de uma matéria que constitui minúscula parcela do universo" (Caraveo e Roncadelli, p. 32).

Feitas tais observações, que tipo de coisas poder-se-ia pensar a este respeito? Uma alternativa seria elaborar um discurso similar ao dos eliminativistas em relação à esperança de avanço das neurociências, e, transferindo tal discurso para a astrofísica contemporânea, confiar na possibilidade de que o desenvolvimento teórico e a pesquisa empírica pertinente ao assunto venham a fornecer um quadro teórico adequado acerca de toda a constituição do universo.

Se a alternativa que especulamos acima fizer algum sentido, temos boas razões para esperar que nem mesmo o mais otimista dos materialistas a leve em consideração; afinal, haveria esperança demais, e, no mínimo, abuso de linguagem se considerar um materialista que, mesmo reconhecendo que a ciência atual desconheça o que seja matéria, ainda assim se entenda enquanto tal (um materialista). Porém, pode-se objetar que a matéria escura é apenas mais difícil de observar, de modo que, no futuro, ela poderia vir a ser conhecida detalhadamente.

Uma outra alternativa seria concebermos uma metafísica naturalista (note que não é necessário que se abra mão de uma posição naturalista) menos dogmática e verdadeiramente atenta aos conhecimentos atuais (que conduzem à idéia de que quase nada sabemos acerca das propriedades e constituição de toda a matéria existente). Numa

ondas de rádio, raios $\mathrm{X}$ e gama - é apenas uma parcela insignificante de toda a matéria que exerce uma função gravitacional. Este é o famoso problema da "matéria escura", um dos desafios mais estimulantes da astrofísica 
perspectiva desse tipo, presume-se que novidades poderiam surgir dependendo do que venha a ser feito em astrofísica ou investigações sobre a constituição da matéria. Nem mesmo a possibilidade de se pensar no ressurgimento do dualismo (seja de que tipo for) seria algo despropositado ou inconcebível. Como observa Chomsky (2000):

Suponha que a matéria escura venha a ser crucialmente diferente dos $10 \%$ do mundo sobre o qual fazemos algumas idéias. A possibilidade não pode ser descartada em princípio; coisas estranhas têm sido aceitas na ciência moderna. Isso não pode ser excluído no caso das teorias da mente. Embora não haja razão para considerar a hipótese, alguma versão do cartesianismo (com um conceito de corpo mais rico) poderia em princípio tornar-se verdadeira, consistente com a postura naturalista (p. 85) ${ }^{45}$.

Independentemente do tipo de concepção dos estados mentais que se possa extrair das hipóteses de Chomsky, o que cabe ressaltar é a idéia (com a qual concordamos absolutamente) de que investigações de orientação naturalista não podem cristalizar-se no sentido de aceitar como fatos estabelecidos as noções de corpo e matéria vigentes, como faz grande parte dos que se dizem materialistas. Pois caso não se esclareça a questão sobre o que são entidades materiais, carecerá de sentido arrogar-se materialista.

O naturalismo metafísico será uma posição coerente se seus advogados nos disserem a que equivale o "físico" ou o "material". Até que isso seja feito, nós não poderemos compreender essa doutrina, que nos deixa somente noções derivadas como "materialismo eliminativo" e coisas parecidas. Na prática, versões tais como essa última parecem ser um pouco mais que pronunciamentos acerca de onde as coisas se encontram, assim, não são de especial interesse (Chomsky, 2000, p. 85-86) ${ }^{46}$.

atual" (Caraveo e Roncadelli, 2002, p. 27).

45 "Suppose dark matter turns out to be crucially different from the 10 per cent of the world about which there are some ideas. The possibility cannot be discounted in principle; stranger things have been accepted in modern science. Nor can it be excluded in the case of theories of mind. Though there is no reason to the entertain the hypothesis, dome version of cartesianism (with a far richer concept of body) could in principle turn out to be true, consistent with a naturalist stance".

46 "Metaphysical naturalism will be a coherent position if its advocates tell us what counts as 'physical' or 'material'. Until that is done, we cannot comprehend the doctrine, let alone such derivative notions as 'eliminative materialism' and the like. In practice, versions of the latter seen to be little more than pronouncements as to where the answers lie and, as such, are of no special interest". 
Assim sendo, ou seja, sem um claro entendimento do que seja uma entidade material, Chomsky entende que não apenas carece de sentido assumir-se como materialista, mas o próprio problema mente-corpo nem pode ser coerentemente formulado. Em suas palavras:

(...) as discussões pressupõem algum antecedente entendimento do que seja físico ou material, do que sejam as entidades físicas. Tais termos tinham algum sentido no escopo da filosofia mecânica, mas o que eles significam num mundo baseado na "força misteriosa" de Newton, ou ainda em noções mais misteriosas como campos de força, espaço curvo, cordas com uma dimensão infinita em um espaço de dez dimensões, ou em qualquer coisa que a ciência conceba para amanhã? Faltando um conceito para "matéria" ou "corpo" ou para "o físico", nós não temos um modo coerente para formular questões sobre o "problema mentecorpo". Esses eram reais problemas da ciência nos dias da filosofia mecânica (Chomsky, 2000, p. 109-110) ${ }^{47}$.

Nesta perspectiva, entendendo Chomsky que sem uma noção clara do que se entende por físico ou material, não apenas o problema mente-corpo sequer pode ser formulado, mas também se autodenominar como materialista careceria de sentido. Dito isso, gostaríamos de salientar uma observação aventada por Chomsky na citação precedente que julgamos ser muito apropriada, e que se configura num duro golpe aos materialistas contemporâneos que julgam despropositadas as discussões acerca da relação mente-corpo na perspectiva cartesiana.

Segundo Chomsky, a questão da unificação, quer dizer, da conciliação da filosofia mecânica (que como salientamos, em sua perspectiva cartesiana, pintava o universo físico como sendo um plenum de matéria extensa) com o universo mental (que tem na res cogitans a entidade fundamental, e que devido a suas propriedades encontradas unicamente

\footnotetext{
47 "The discussions presuppose some antecedent understanding of what is physical or material, what are the physical entities. These terms had some sense within the mechanical philosophy, but what do they mean in a world based on Newton's "mysterious force", or still more mysterious notions of fields of force, curved space, infinite one-dimensional strings in ten-dimensional space, or whatever science concocts tomorrow? Lacking a
} 
no homem, caracteriza sua distinção em relação aos animais e máquinas) era uma questão de ciência normal, naturalista por excelência, pois se pautava nos conhecimentos factuais da época. Ademais, Descartes tinha uma idéia do que queria dizer ao empregar termos como matéria e espírito (ver cap. 1). O problema era entender a interação ${ }^{48}$.

Tal quadro de ciência normal legado pela perspectiva cartesiana, segundo Chomsky, teria ruído com a concepção newtoniana de interação à distância, algo que rompia com o modelo de interações por contato da filosofia mecânica. Nas palavras do autor:

\begin{abstract}
A teoria cartesiana colapsou logo depois, quando Isaac Newton mostrou que os movimentos terrestres e planetários iam além dos limites da filosofia mecânica além do que era entendido por corpo, ou matéria. O que permaneceu era um quadro do mundo que era "antimaterialista", e que "confiava pesadamente em forças espirituais" (p. 108) $)^{49}$.
\end{abstract}

Deste modo, pode-se dizer que a conclusão de Chomsky é a de que, na perspectiva cartesiana, a relação mente-corpo se colocava como um problema real, passível de ser abordado de forma naturalista; ao passo que após o colapso da filosofia mecânica que se seguiu à publicação das idéias de Newton, o problema mente-corpo sequer pode ser formulado de maneira inteligível, como era no contexto do mecanicismo cartesiano. Isso porque o universo físico não possuía mais a inteligibilidade de outrora. Em suma, estes seriam os problemas que podem ser dirigidos às abordagens materialistas da mente.

concept of 'matter' or 'body' or 'the physical', we have no coherent way to formulate issues related to the "mind-body problem". These were real problems of science in the days of the mechanical philosophy".

48 “O 'problema da unificação' era uma questão sobre a interação do corpo com a mente. Esse dualismo metafísico era naturalístico em essência, usando evidencias empíricas para teses factuais sobre o mundo teses erradas, mas mesmo assim, essa era a regra" (Chomsky, 2000, p. 108).

49 "The cartesian theory collapsed soon after, when Isaac Newton showed that terrestrial and planetary motion lie beyond the bounds of the mechanical philosophy - beyond what was understood to be body, or matter. What remained was a picture of the world that was 'antimaterialist', and that 'relied heavily on spiritual forces"”. 
No próximo capítulo, apresentaremos uma outra abordagem de caracterização da mente, que, apesar de sua inspiração materialista, escapa às objeções formuladas acima por conceber a mente em termos funcionais. 
Capítulo 3 - A proposta funcionalista da mente 


\section{Apresentação}

Visto que, a partir das críticas de caráter lógico dirigidas à teoria da identidade mente-cérebro, um determinado estado mental pode ser pensado como um tipo ou uma generalidade de tokens, avaliaremos, neste terceiro capítulo, a maneira como tal perspectiva teórica permite que se possa compreender os estados mentais em termos de organizações funcionais.

Sendo assim, apresentaremos, num primeiro momento, as linhas gerais do que se convencionou chamar de projeto funcionalista, para, em seguida, avaliarmos o alcance da perspectiva delineada por Shoemaker (1980) (que entende que os estados qualitativos podem ser definidos funcionalmente).

Num segundo momento, resgataremos o que entendemos ser o sentido profundo da noção de experiência, para, a rigor, nos posicionarmos acerca das conjecturas de Shoemaker, bem como sobre que tipos de explicações o problema da experiência consciente demanda.

Num terceiro momento, avaliaremos numa perspectiva em particular (a de Ryle, 2000), a maneira como a dimensão epistemológica do problema mente-corpo e da experiência podem ser, senão resolvidos, ao menos minimizados mediante acurada análise lógica da linguagem.

Finalmente, traçaremos as linhas gerais das perspectivas futuras a serem investigadas, em que as noções desenvolvidas por Chalmers $(1996,1997)$ de 'espaço de informação’ e duplo ‘aspecto da informação’ se constituem em elementos centrais. 


\section{1 - O funcionalismo}

Como indicamos na seção anterior, a partir de algumas objeções de caráter lógico dirigidas à teoria da identidade, surge uma espécie de evolução desta, em que um dado estado mental passa a ser concebido como um tipo, ou melhor, uma generalidade de tokens (em que um estado mental especifico passa a ser entendido em termos mais abrangentes, podendo ser atribuído, sem nenhum empecilho lógico, a organizações cerebrais diferentes). Com isso, pode-se dizer, abre-se precedente para se pensar na dor (entendida em termos gerais), por exemplo, em termos de sua organização funcional.

Nessa perspectiva, os estados mentais podem ser comparados a estados funcionais de um computador, de modo que assim como um programa de computador ou software se realiza em diferentes configurações de hardware, analogamente, um "programa psicológico", hipoteticamente, poderia se realizar em variados sistemas biológicos, bem como artificiais. Como observa Abrantes (1993), a respeito dessa hipótese geral do funcionalismo:

Tal posição em filosofia da mente se caracteriza pela tese de que é possível fazer abstração, no estudo dos processos cognitivos, de uma 'particular instanciação' material (física, biológica) dos processos mentais. Esses processos poderiam ser descritos exclusivamente em termos de uma organização funcional da mente, em que, por exemplo, "módulos" desempenhariam funções especificadas por relações de processamento entre a entrada (input) e a saída (output). (...) Os estados mentais são caracterizados exclusivamente por suas inter-relações funcionais, podendo ser "instanciados" nos mais diversos materiais, seja em silício, seja em estruturas biológicas como os cérebros dos animais (p. 11).

A hipótese funcionalista geral que delineamos acima, em que as instâncias materiais que sustentam os estados mentais são entendidas como não sendo determinantes para a real 
compreensão dos fenômenos mentais, é com frequiência associada a alguma variante de funcionalismo de máquina, que teria como um dos precursores a figura de Hilary Putnam ${ }^{50}$.

Como não pretendemos explicitar detalhadamente as sutilezas que caracterizam a proposta funcionalista de Putnam, façamos apenas algumas observações de caráter geral acerca da hipótese funcionalista, com o intuito de assinalarmos o modo como essa hipótese influenciou os desenvolvimentos observados na ciência cognitiva.

A despeito do funcionalismo inspirar-se no materialismo, que, como salientamos, remonta às teorias da identidade mente-cérebro, interessa notar que a abordagem funcionalista, na perspectiva computacional mencionada acima, não enfatiza propriamente questões relacionadas ao que seja a mente humana, devendo ser concebida, antes, como uma espécie de metáfora, capaz de lançar uma luz sobre a relação mente-corpo, podendo, talvez, auxiliar na tarefa de remoção de alguns problemas (em geral conceituais) que são salientes nas abordagens dualistas e materialistas ${ }^{51}$.

Feitas algumas considerações gerais sobre a abordagem computacional da mente, resta mencionar que essa perspectiva assenta-se na hipótese de que a mente opera em

\footnotetext{
${ }^{50}$ Pelo menos do que se convencionou chamar de primeiro Putnam, pois a partir do início dos anos 80 ele abandona suas posições iniciais.

${ }^{51}$ Talvez os principais problemas do materialismo passíveis de serem contornados pelo funcionalismo computacional estejam relacionados à problemática noção de matéria, pois como discutimos ao final do capítulo 2, tal noção (fundamental nas abordagens materialistas) encerra, para alguns críticos, sérios problemas. Em razão do funcionalismo computacional não estar comprometido com a noção de matéria, não significa que ele seja absolutamente incompatível com o materialismo. Como Putnam (1980) ressalta, a hipótese funcional da mente se apresenta como uma espécie de terceira via entre o materialismo e o dualismo, não se colocando, necessariamente, como uma posição incompatível com tais perspectivas. A aproximação do funcionalismo com o materialismo fica bastante evidente em seu artigo originalmente publicado em 1975 (Minds and machines), em que Putnam defende o que chama de identidade teorética entre estados mentais e estados cerebrais. Resumidamente, o referido autor entende que não estaria excluída a possibilidade de que, no futuro, a identificação entre estados mentais e cerebrais possa vir a ser expressa num enunciado (tal como 'estados mentais são iguais a estados cerebrais') inteligível, no contexto de uma futura teoria materialista da identidade mente-cérebro; mais ou menos como ocorreu após a formulação dos princípios da eletrólise, em que o enunciado 'água é igual a H2O', passou a ter sentido. Já em relação à não necessária incompatibilidade entre o funcionalismo e o dualismo, Putnam entende (sem evocar a idéia de alma) que o funcionalista pode, sem incorrer em impropérios lógicos, se referir a funções como sendo propriedades não físicas; algo que para Smart, por exemplo, careceria de sentido. Cf. Putnam (1980, p. 228).
} 
termos de estruturas representacionais manipuladas por procedimentos computacionais. Como observa Block (1980):

O funcionalismo computacional-representacional aplica-se num importante caso de explicação funcional, nomeadamente, na explicação psicológica vista como análoga a um programa de computador para a mente. Qualquer mistério sobre nossa vida mental pode ser inicialmente dissolvido pela análise funcional dos processos mentais a partir de um ponto onde eles podem ser vistos como computações mecânicas de um computador digital. As noções-chave nesta perspectiva são as de computação e representação. Estados psicológicos são vistos como sistematicamente representando o mundo por via de uma linguagem do pensamento, e processos psicológicos são vistos como computações sobre tais representações (Block, 1980, p. 171) ${ }^{52}$.

Atentando à caracterização do funcionalismo computacional fornecida por Block na passagem acima, percebe-se que o que torna essa orientação teórica tão influente na ciência cognitiva reside na possibilidade aberta pelo funcionalismo de se compreender os processos mentais em termos de computações mecânicas efetuadas por um computador digital; algo que, em termos científicos (e também filosóficos), seria muito atraente, por possibilitar que hipóteses sejam testadas mediante modelagem computacional ${ }^{53}$.

Assim como no contexto do funcionalismo as noções de representação e computação seriam de grande importância, pode-se dizer que elas seriam igualmente centrais no contexto da ciência cognitiva, que reconhece na modelagem computacional uma

\footnotetext{
52 "Computation-representation applies to an important special case of functional explanatory, namely, to psychological explanation seen as akin to providing a computer program for the mind. Whatever mystery our mental live may initially seem to have is dissolved by functional analysis of mental processes to the point where they are seen to be composed of computation as mechanical as the primitive operations of a digital computer. The key notions of functionalism in this sense are representation and computation. Psychological states are seen as systematically representing the world via a language of thought, and psychological processes are seen as computations involving these representations".

${ }^{53} \mathrm{Um}$ dos fatores que tornam a abordagem funcionalista muito influente consiste na possibilidade que tal perspectiva traz em seu bojo de se conceber a relação mente-corpo sem o comprometimento com uma prédefinição de matéria, tampouco, hipóteses metafísicas ad hoc tais como um bon Dieu responsável pela união da mente com o corpo ou uma harmonia pré-estabelecida.
} 
de suas características essenciais. Como observa Fodor (1975): “Sem representação, não há computação; sem computação, não há modelagem” (p. 31) ${ }^{54}$.

Determinar a natureza das estruturas representacionais e do que venha a ser uma computação é uma tarefa das mais complicadas, que em muito extrapola os limites do presente trabalho; mas para que nosso discurso não soe demasiado evasivo, façamos um breve parêntese, e, muito rapidamente, vejamos algumas características que compõem tais noções ${ }^{55}$.

Para compreendermos a noção de representação, e, particularmente, a de representação mental (noção fundamental em filosofia da mente), façamos uma breve incursão pela história da filosofia, e pensemos inicialmente em Platão. Para este, com efeito, o autêntico conhecimento adviria de um mundo ideal, ou mundo das formas (que seriam imutáveis e eternas). Porém, por não podermos acessá-lo diretamente por meio de nossos sentidos, o "contato" com tal mundo teria de ser intelectual. Além disso, a intelecção conceitual dos arquétipos perfeitos já estaria presente na mente humana desde o nascimento, sendo preciso, somente, que nos lembremos mediante o exercício filosófico e conseqüente depuração ou aperfeiçoamento conceitual.

Na alegoria do mito da caverna (A república, 1949, livro VII), seríamos como que prisioneiros acorrentados em uma escura caverna, que, de costas para a entrada, contemplaríamos as sombras que se projetam numa parede em nossa frente devido a uma

\footnotetext{
54 "Without representation, there is no computation; without computation, there is no modeling".

${ }^{55}$ A bem da verdade, vejamos apenas a noção de representação. Quanto à noção de computação, basta dizer, de maneira muito simplificada, que esta consiste na aplicação de determinadas regras ou operações sobre premissas. Das regras mais usuais de inferência que possibilitam tirar conclusões por meio do uso de condicionais, podemos citar o modus ponens, que possui a seguinte forma lógica: $\mathrm{p} \rightarrow \mathrm{q}$; $\mathrm{p}$; conseqüentemente, q. E o modus tollens, que seria: $\mathrm{p} \rightarrow \mathrm{q} ; \neg \mathrm{q}$; conseqüentemente, $\neg \mathrm{p}$.
} 
fogueira situada atrás de nós. Essas sombras, ou simulacros seriam tudo o que tomamos por realidade, de modo que o que se passa no exterior da caverna nos seria vedado aos sentidos.

Com essa alegoria, Platão pretende dizer que a realidade em si mesma só pode ser apreendida mediante o exercício filosófico, ou labor intelectual, que visa trazer à tona os conceitos inatos da mente; de modo que as sombras projetadas no fundo da caverna que tomamos por realidade seriam meras aparências.

Uma idéia que podemos extrair dessa alegoria platônica é a de que assim como o mundo no qual estamos imersos seria, para Platão, uma espécie de "imagem enganosa" que fazemos a respeito de uma realidade supra sensível, analogamente, uma representação pode ser entendida como uma espécie de "cópia" de alguma coisa, mais ou menos como um mapa pode representar uma ilha, por exemplo.

Restringindo um pouco essa noção intuitiva e um tanto geral de representação, podemos dizer que uma representação mental seria uma espécie de cópia do mundo que criamos mentalmente. Na modernidade, em especial, para Descartes, por exemplo, uma representação mental equivaleria a uma idéia ou "imagem das coisas", que pode se manifestar tanto imageticamente, quanto em termos de números ou gráficos, bem como em termos de conteúdos proposicionais expressos por meio da linguagem natural. Ademais, as representações mentais pertenceriam ao domínio da res cogitans, não sendo, portanto, entidades físicas.

Como indicamos, o que caracteriza uma representação é sua propriedade de ser "algo" que pode se colocar no lugar de "outra coisa" (como um mapa, por exemplo). No contexto da ciência cognitiva, aos sistemas a que se atribuam representações (que podem ser artefatos tanto da inteligência artificial quanto conexionistas), pode-se dizer que elas (as 
representações) seriam dotadas de conteúdo (que varia dependendo da abordagem), e visariam sobretudo, guiar o comportamento. Como afirma Haselager (2005):

\begin{abstract}
As duas características mais importantes das representações são que elas se colocam no lugar de algo e que o sistema usa as representações com o objetivo de guiar seu comportamento. De acordo com a ciência cognitiva tradicional, então, as representações desempenham um duplo papel: carregam um conteúdo e causam o comportamento. Mesmo se a ciência cognitiva clássica e o conexionismo discordam a respeito do formato das representações, eles têm esse pressuposto em comum (p. 106).
\end{abstract}

Fornecidas as bases representacionais que definem o funcionalismo em sua concepção mais geral, pode-se dizer que por meio da metáfora do computador (ou seja, por meio da compreensão da mente em termos de estruturas representacionais manipuladas por operações computacionais), a ciência cognitiva pôde se desenvolver de maneira marcante em razão da possibilidade de teste de hipóteses mediante modelagem computacional. Assim, entendemos que talvez não seja forçoso dizer que tanto a ciência cognitiva quanto o funcionalismo computacional tendem a enfatizar, sobretudo, as explicações acerca do modo de funcionamento da mente, do que fornecer propriamente esclarecimentos acerca de sua natureza.

Mas isso não significa que o funcionalismo não possa ser pensado numa perspectiva em que a natureza da mente venha a fazer parte de seu horizonte investigativo. Como observa Block (1980), numa perspectiva funcionalista de caráter metafísico o que mais interessa "é uma teoria da natureza da mente, de preferência a uma teoria da explicação psicológica. Funcionalistas metafísicos se preocupam não com o modo como estados mentais explicam o comportamento, mas com o que eles são" (p. 172)

\footnotetext{
56 “(...) Is a of the nature of the mind, rather than a theory of psychological explanation. Metaphysical functionalists are concerned not with how mental states account for behavior, but rather with what they are".
} 
Nessa perspectiva, alguns funcionalistas entendem que para a compreensão do que venha a ser a real natureza da mente, o entendimento das bases materiais que a sustentam é de vital importância; de modo que para uma dor manifestada num dado organismo, por exemplo, talvez haja um único tipo de estado físico capaz de instanciá-la. Como observa Block (1980):

Muitos funcionalistas estão dispostos a levar em consideração que cada dor particular seja um estado ou evento físico, e que, de fato, para cada tipo de sentimento de dor de um organismo (talvez) haja um único tipo de estado físico que realize tal dor naquele tipo de organismo (p. 172) ${ }^{57}$.

Nesta perspectiva funcionalista que valoriza o papel das bases materiais que sustentam a mente, não é necessária a discordância com o fisicalismo, no sentido de que as entidades e eventos que constituem o universo sejam físicos. A discordância se daria com relação ao que une as entidades umas às outras, e norteiam os eventos que se dão no universo. Para o funcionalista, seriam propriedades funcionais; ao passo que para o fisicalista não funcionalista, seriam propriedades físicas. Neste sentido, segundo Block (1980), a diferença entre funcionalistas, fisicalistas e também behavioristas, seria metafísica, sem ser ontológica ${ }^{58}$.

Para a caracterização da dor (para dar continuidade ao exemplo que viemos explorando), numa perspectiva funcionalista que Block (1980) chama de metafísica, com efeito, esta poderia ser caracterizada em termos de seus papéis causais com relação aos

\footnotetext{
57 "Most functionalists are willing to allow that each particular pain is a physical state or event, and indeed that for each type of pain feeling organism, there is (perhaps) a single type of physical state that realizes pain in that type of organism".

58 "O desacordo entre funcionalistas e fisicalistas (e behavioristas) é metafísico sem ser ontológico. Funcionalistas podem ser fisicalistas em conceber que todas as entidades (coisas, estados, eventos, e outras) que existem são entidades físicas, negando somente que o que une tais tipos de coisas são propriedades físicas" (Block, 1980, p. 174).
} 
estímulos sensoriais, comportamentos manifestos e outros estados mentais. Segundo o

referido autor:

Funcionalistas metafísicos caracterizam os estados mentais em termos de seus papéis causais, particularmente, em termos de suas relações causais com estímulos sensoriais, comportamentos manifestos, e outros estados mentais. Assim, por exemplo, numa teoria funcionalista metafísica, a dor pode ser caracterizada, em parte, em termos de tender a surgir quando um tecido é danificado, por sua tendência de causar o desejo de que tal dor seja eliminada, e pela tendência de provocar o desejo de tratar tal dor, produzindo ações no sentido de eliminar a causa da dor, tratando a parte do corpo afetada (p. 172) ${ }^{59}$.

Entretanto, alguns autores entendem que a compreensão da dor em termos de seus papéis causais, com relação aos estímulos sensoriais, comportamentos manifestos e outros estados mentais, seria insuficiente para a compreensão de sua principal característica, qual seja, de seu caráter qualitativo. Isso porque tal caráter (supõem os críticos) não poderia ser funcionalmente definido.

Shoemaker (1980), porém, entende ser perfeitamente possível definir funcionalmente o estado mental de dor (com seu conteúdo qualitativo), por exemplo, desde que se tome como uma classe de estados mentais, justamente tais aspectos qualitativos, e, mediante a noção de similaridade qualitativa, defina numa tabela as variedades que um certo tipo de estado qualitativo pode assumir. Nas palavras do autor:

\begin{abstract}
Se os estados mentais podem ser parecidos ou diferentes no que diz respeito ao 'caráter qualitativo', nós podemos falar de uma classe de estados chamada 'estados qualitativos', cujas 'condições de identidade de tipo' podem ser especificadas em termos da noção de similaridade qualitativa (ou 'fenomenológica'). Para cada caráter qualitativo determinado que um estado pode ter, existe (isto é, podemos definir) um estado qualitativo determinado que
\end{abstract}

\footnotetext{
59 "Metaphysical functionalists characterize mental states in terms of their causal roles, particularly, in terms of their causal relations to sensory stimulations, behavioral outputs, and other mental states. Thus, for example, a metaphysical functionalist theory of pain might characterize pain in part in terms of its tendency to be caused by tissue damage, by its tendency to cause the desire to be rid of it, and by its tendency to produce action designed to separate the damage part of the body from what is thought to cause the damage".
} 
uma pessoa tem apenas no caso de ela ter um estado que tenha precisamente aquele estado qualitativo (p. 253) ${ }^{\mathbf{6 0}}$.

Porém, antes de explicitarmos a maneira como Shoemaker entende que os aspectos qualitativos podem ser definidos funcionalmente (em que a noção de similaridade qualitativa seria central), avaliemos alguns argumentos baseados em experiências de pensamento que se colocam como entraves à possibilidade de se definir funcionalmente o estado qualitativo da dor, por exemplo.

Sendo assim, podemos dizer que as considerações de Shoemaker acerca da possibilidade de se definir funcionalmente os estados qualitativos se articulam como resposta a um artigo de Block \& Fodor (1980), em que estes, resumidamente, afirmam que as qualidades da experiência não podem ser funcionalmente definidas devido aos problemas representados pelos argumentos dos qualia invertidos e dos qualia ausentes.

A objeção dos qualia invertidos afirma que não haveria nenhum absurdo em se conceber que determinadas cores que o individuo $\mathrm{X}$, por exemplo, percebe, possam ser invertidas em relação às cores percebidas pelo indivíduo Y. Ao observar um morango, por exemplo, Y pode ter uma sensação de verde, ao passo que o individuo $\mathrm{X}$ poderia ter a sensação de vermelho, e vice-versa. Como não haveria meios do individuo $\mathrm{X}$ "entrar na cabeça" do sujeito Y para experienciar suas qualidades fenomênicas, e, como as distinções relatadas por X e Y permanecerão iguais ${ }^{61}$, não haveria meios de determinar a diferença na sensação das cores observadas.

\footnotetext{
60 "If mental states can be alike or different in 'qualitative character', we should be able to speak of a class of states, call them 'qualitative states', whose 'type identity conditions' could be specified in terms of the notion of qualitative (or 'phenomenological') similarity. For each determinate qualitative character a state can have, there is a determinate qualitative state which a person has just in case he has a state having precisely that qualitative character".

${ }^{61}$ No sentido de que ao observarem, por exemplo, uma maçã, uma cereja e um morango, ambos os sujeitos se referirão a tais frutas como sendo vermelhas.
} 
Assim, Block \& Fodor (1980) argumentam que, na medida em que, funcionalmente, as observações de $\mathrm{X}$ e $\mathrm{Y}$ são isomórficas, então a sensação de $\mathrm{Y}$ ver um morango maduro, por exemplo, será descrita como a sensação de ver algo vermelho (mesmo que "o vermelho de Y", ou melhor, a qualidade experienciada por $\mathrm{Y}$ ao ver o vermelho, seja radicalmente distinta da sensação de X). Ou seja, se a observação de Y preencher as condições funcionais para suscitar uma sensação que Y chama de vermelho, então, por definição, ele tem uma sensação de vermelho, mesmo que o "seu vermelho" seja diferente (pareça verde, por exemplo) do que X experimenta.

A objeção ao funcionalismo seria a seguinte: caso o funcionalismo sustente que uma inversão do tipo que descrevemos acima não seja possível, então ele está equivocado, na medida em que tal inversão é logicamente possível.

Para Shoemaker, entretanto, tal objeção poderia ser contornada, na medida em que estaria aberta ao funcionalista a possibilidade de negar que as sensações devam ser qualitativamente idênticas (p. 252). Assim, no caso das cores, por exemplo, pode ocorrer que a sensação visual derivada da contemplação de tomate maduro que experimento, seja diferente da experimentada por fulano ou sicrano. Mas desde que essa cor seja causada por objetos vermelhos, tais como um morango ou uma cereja, então todas as cores desse tipo podem ser concebidas como um tipo de experimentação de uma cor em particular. Em resumo, as qualidades específicas não são essenciais para a identidade de tipo dos estados mentais.

Já a segunda objeção, a dos qualia ausentes, Block e Fodor (1980) assim a formulam: 
Em relação a tudo o que nós conhecemos agora, é nomologicamente possível para dois estados psicológicos serem funcionalmente idênticos (isto é, para serem identicamente conectados com inputs, outputs, e estados sucessores), mesmo que apenas um dos estados tenha um conteúdo qualitativo (p. 245) ${ }^{62}$.

O que Block e Fodor sugerem na passagem acima é que a possibilidade de que possa haver duas organizações funcionais com apenas uma delas possuindo conteúdo qualitativo indica que, no mínimo, o funcionalismo forneceria uma caracterização incompleta dos estados mentais.

Para responder a essa objeção, Shoemaker (1980), inicialmente, discrimina três critérios que devem ser satisfeitos para que um estado funcional equivalha a um estado de dor. Em primeiro lugar, tal estado deve tender a influenciar outros comportamentos de uma dada maneira; em segundo lugar, ser capaz de produzir a crença de que algo está errado, e, finalmente; produzir crenças qualitativas na pessoa, fazendo-a pensar ter uma dor com um certo caráter qualitativo em específico (de desprazer, no caso) (p. 254).

Em relação ao terceiro critério, qual seja, o de que um estado funcionalmente idêntico ao estado de dor deve ser capaz de criar uma crença qualitativa, pode-se dizer que esta (crença qualitativa) seria algo oriunda da própria experiência de sentir uma dor; ou seja, uma crença derivada do próprio acesso a certos tipos de conteúdos mentais, que permitem fazer crer que se está sentindo algo de uma dada maneira (Shoemaker, p. 254).

Fornecidos tais critérios que um estado funcional deve satisfazer para ser identificado como um estado de dor, poder-se-ia dizer que, levando-se em consideração o argumento dos qualia ausentes, mesmo que um determinado estado seja funcionalmente

\footnotetext{
62 "This form of argument may, however, lead to embarrassing consequences. For all that we now know, it may be nomologically possible for two psychological states to be functionally identical (that is, to be identically connected with inputs, output, and successor states), even if only one of states has a qualitative content".
} 
idêntico ao de dor, quer dizer, mesmo que os critérios mencionados acima sejam satisfeitos, ainda assim, o argumento sugere que tal estado pode não apresentar caráter qualitativo.

Considerando essa possibilidade em que, de fato, o problema dos qualia ausentes seja possível, Shoemaker (1980) indaga: "Como poderíamos detectar que tais casos ocorrem?" (p. 254) ${ }^{63}$. Ou seja, numa situação em que houvesse dois estados funcionalmente idênticos, com apenas um desses estados possuindo caráter qualitativo, como poderíamos determinar qual deles seria o possuidor de conteúdo qualitativo?

Colocada a questão nesses termos, Shoemaker observa que não teríamos meios de responder com absoluta certeza tal tipo de questionamento, na medida que, se duas pessoas são funcionalmente idênticas, então seus discursos e gestos manifestos também o são, e, como não se possui meios de inspecionar diretamente as qualidades da experiência de terceiros, o referido autor chega a reconhecer que talvez seja mesmo de bom grado admitir que as tais qualidades não existem (p. 255).

Mas essa não é a real posição defendida por Shoemaker. Afinal, o autor reconhece que em seus discursos usuais, as pessoas fazem constantemente menção à intensidade de dores que as acometem, e, com base em tais observações e o reconhecimento das próprias sensações que cada um possui, haveria boas razões para supor que os conteúdos qualitativos existem. Assim, diante disso, Shoemaker inclina-se a aceitar que tais conteúdos não apenas existem como são passíveis de serem definidos funcionalmente; pois desempenham papéis causais com relação a outros estados mentais e comportamentos. Em suas palavras:

Essa objeção não pode tocar um importante ponto implícito em meu argumento, nomeadamente, que nós não podemos negar, sem sermos comprometidos com um ceticismo intolerável sobre as dores alheias, que quando alguém diz que

\footnotetext{
63 "How might we detect such a case if it occurred?".
} 
sente uma dor aguda, esta é uma boa evidência de que ele tem um estado qualitativo e não outro, e é assim porque quando alguém diz isso, normalmente, está manifestando um efeito de seu caráter qualitativo (p. 256) ${ }^{64}$.

O que está por trás de tais considerações de Shoemaker, a rigor, é o que ele chama de teoria causal do conhecimento, que afirma que estados de coisas independentes de poderes causais são incognoscíveis. Nos termos do autor:

De fato, exatamente como uma teoria causal do conhecimento poderia implicar que estados ou características que são independentes dos poderes causais de coisas que eles caracterizam, poderiam ser, em princípio, incognoscíveis assim como uma teoria causal da referência pode implicar que seus estados e características são, em princípio, inomináveis e inacessíveis para a referência (p. $255)^{65}$.

Sendo assim, a posição de Shoemaker é a de que o argumento dos qualia ausentes faz menção a um estado de coisas que não pode existir. Isso porque, cotidianamente, experienciamos indubitavelmente cores, odores, etc., de modo que com base na teoria causal do conhecimento o argumento dos qualia ausentes seria, no mínimo, contraintuitivo.

Com isso, ou seja, sem a relação causal estabelecida entre os conteúdos qualitativos e o comportamento, Shoemaker entende que não poderíamos fazer a menor idéia a respeito de tais conteúdos; mas como ele julga difícil negar a realidade das sensações que nos acometem (não apenas com base na freqüência com que as pessoas se referem às suas sensações, mas também com base em suas próprias experiências qualitativas), e, por questão de bom senso, o autor entende que se deve considerar o

\footnotetext{
64 "This objection does not touch one important point implicit in my argument, namely that we can not deny, without being committed to an intolerable skepticism about the pain of others, that someone's saying that he feels a sharp pain is good evidence that he has some qualitative state or other, and is so because someone's saying this is, normally, an effect of his having a state having qualitative character"
} 
argumento dos qualia ausentes como sendo implausível.

Fornecida a maneira como Shoemaker contorna o problema dos qualia ausentes, vejamos na próxima seção o modo como o Shoemaker entende ser possível definir funcionalmente um estado qualitativo, em que o referido autor lança mão da noção de similaridade qualitativa.Vejamos também o sentido profundo que entendemos haver na formulação do problema dos qualia que faz com que, em nosso entender, a possibilidade de se definir (ou não) um dado aspecto qualitativo não se coloca no horizonte de uma solução ao problema. Por último, avaliemos uma perspectiva que, se não resolve o problema mentecorpo, bem como o dos qualia, ao menos possibilita que, no plano epistemológico, a relação mente-corpo não se coloque como algo ininteligível, fora do plano da teoria e previsibilidade.

\footnotetext{
65 "Indeed, just as a causal theory of knowledge would imply that states or features that are independent of the
} causal powers of the things they characterize would be in principle unknowable, so a causal theory of 


\section{2 - Mente, linguagem e perspectivas futuras}

Como a saída do argumento dos qualia invertidos sugere, os conteúdos qualitativos não precisam, necessariamente, ser específicos. Desde que eles sejam de um determinado tipo (como a dor, por exemplo, entendida em termos genéricos), Shoemaker entende que eles podem ser funcionalmente definidos mediante a especificação das similaridades entre os vários matizes de dor em uma tabela.

Como salientamos acerca da sensação do vermelho (seção 3.1), por exemplo, sendo a sensação dessa cor causada por determinados objetos, e, seguindo-se à experimentação dessa cor certos tipos de ações (como o de comer uma maçã que se julga madura pelo exame de sua cor), Shoemaker entende ser perfeitamente possível quantificar os matizes de vermelho, discriminando-os numa tabela enquanto um tipo de qualidade, que, ressaltemos, manteriam relações causais com certos tipos de comportamento.

Quanto aos pormenores teóricos e técnicos de como e em quais artefatos se poderia instanciar os matizes de uma cor e que tipos de reação se seguiria à detecção de uma determinada cor, por exemplo, podemos apenas dizer que no presente texto tais particularidades não serão investigadas. Sendo assim, um ponto que gostaríamos de resgatar diz respeito à própria noção de qualia ou experiência consciente.

Como observa Nagel (1974), o que faz como que o problema dos qualia pareça intratável reside em sua própria constituição ou formulação que aventa à idéia de que a menos que se construa um "cerebroscópio" capaz de fazer com que um dado indivíduo experiencie as sensações alheias (algo aparentemente distante da ciência atual), tal

reference would imply that such states and features are in principle unnamable and inaccessible to reference". 
problema (o dos qualia) se colocará terminantemente como algo inacessível à ciência contemporânea. Ou seja, para o referido autor, bem como para Jackson (1986), existe um determinado tipo de conhecimento que jamais poderá ser alcançado pelo materialismo, qual seja, o conhecimento de ser como (what is it like) um outro ser que não nós mesmos (em especial, se este ser se tratar de uma criatura bastante distinta de um ser humano).

Em outras palavras, entendemos que a resposta para o problema dos qualia demanda algo mais que a mera quantificação de símbolos numa tabela (algo perfeitamente possível de ser realizado). E este algo a mais seria a experiência intersubjetiva direta das afecções ou sentimentos de outrem.

Entendemos, em suma, que a própria formulação do problema dos qualia não admite uma resposta meramente "teórica" ou "objetiva", pois como Jackson com seu exemplo da neurocientista Mary aventa, a experiência encerra conhecimentos que ultrapassam os saberes que se pode extrair tanto do funcionamento do cérebro quanto de uma máquina (seja ela qual for).

Mas o quê queremos dizer com esta desestimulante perspectiva delineada nas linhas acima? Será que devemos cair num ceticismo total a ponto de pensar, a exemplo de Huxley (1973), que cada um de nós se constitui numa miríade de universos insulares? Ou seja, será que no abismo explicativo aventado por Levine (1983) as “duas margens” hão de permanecer terminantemente distantes uma da outra? Neste ponto é preciso que nos posicionemos.

Como demos a entender com o caminho que decidimos trilhar em nossa investigação da relação mente-corpo, o modo como uma mente experiencia algo só pode ser compreendido em sua totalidade mediante o acesso direto, ou seja, mediante um artifício que possibilite o acesso direto das sensações experimentadas por outros; e isso, 
pensamos, só pode ser alcançado mediante artefatos tecnológicos a serem desenvolvidos, ou como convencionou-se dizer, por meio de uma espécie de "cerebroscópio".

Já no que se refere às condições de possibilidade de que tal artefato possa algum dia vir a ser construído, não nos cabe aqui fazer previsões. Assim, o conhecimento resultante de "ser como outra coisa que não nós mesmos" nos parece uma questão de caráter científico bastante árdua.

Com base no que apresentamos acima, o ceticismo ainda prevalece, na medida em que a ciência nos parece estar longe de responder ao problema dos qualia. Entretanto, epistemologicamente, entendemos que o abismo que parece existir não apenas entre a mente e o corpo de um único ser, bem como entre as sensação que mentes distintas evocam ao experienciarem a cor de uma rosa, por exemplo, pode ser encurtado mediante acurada análise lógica da linguagem e confecção de novos conceitos.

Neste sentido, pensamos que as análises lógico-filosóficas desenvolvidas por Ryle são de grande valia no que tange à compreensão da relação mente-corpo bem como no que tange à indicação de uma perspectiva em que o trato do problema dos qualia possa se dar. Assim, pode-se dizer que uma das primeiras tentativas de análise do problema mente-corpo no século XX deriva diretamente dos estudos de Ryle (2000). Uma proposta de dissolução do problema que, dirigida contra o dualismo substancial, grosso modo, consistiria na idéia de que os corolários da argumentação cartesiana, tais como as embaraçosas dicotomias entre mente/corpo, livre arbítrio/determinação, conteúdos privados/ações manifestas, etc., seriam derivados da má utilização do léxico por parte dos filósofos.

No entanto, esta má utilização do léxico pelos filósofos não consistiria numa má compreensão no plano da ação, ou melhor, por parte do senso comum, de certas noções mentalistas tais como vontade, prazer, temor, etc., pois a maioria das pessoas se comunica 
perfeitamente (ou pelo menos quase perfeitamente), e sabem, ou pelo menos agem como se soubessem, na maioria das vezes, o que querem dizer quando aplicam certas noções problemáticas.

Dito isso, ou seja, havendo problemas lógico-linguísticos no plano da filosofia e não havendo problemas propriamente na utilização corriqueira ou do plano do senso comum que fazemos das noções mentalistas, resta que Ryle se preocupa em estabelecer a correta categorização de tais conceitos mentalistas no plano teórico, que é justamente o âmbito em que emergem os grandes problemas da filosofia da mente. Assim sendo, ou seja, feitas tais distinções entre os planos prático (de senso comum) e teórico da utilização de noções mentalistas, podemos considerar que a proposta de Ryle consiste em desfazer uma serie de equívocos decorrentes da má utilização do léxico mentalista por parte dos filósofos. Nessa perspectiva, ele utiliza a expressão erro categorial para designar tais equívocos cometidos no plano teórico, que seriam a matriz geradora de todos os problemas inerentes ao cartesianismo.

Como ilustração daquilo que entende por erro categorial, Ryle sugere que imaginemos um estrangeiro que ao visitar Oxford ou Cambridge pela primeira vez, interessado em conhecer a universidade, mesmo após ter acesso aos prédios das faculdades, bibliotecas, ginásios poliesportivos, museus e repartições administrativas, ainda assim insiste em perguntar onde está a universidade. Ou seja, mesmo depois de ter conhecido todos os prédios e repartições que, tomados em conjunto, compõem o sistema de universidade, o estrangeiro em questão permanece com seu desejo inicial de conhecê-la.

O ponto a que Ryle pretende chegar com tal exemplo consiste na idéia de que o visitante estrangeiro cometeria um erro categorial por não entender que o conceito de universidade consistiria no conjunto das relações estabelecidas entre os elementos 
averiguados separadamente pelo estrangeiro, e não num prédio ou repartição tomado isoladamente. "Ele situou erroneamente a universidade na mesma categoria a que as outras instituições pertencem (Ryle, 2000, p. 18)",66.

De maneira simplificada, o erro categorial seria uma espécie de equívoco decorrente do mal uso de certas noções, sendo que este mal uso ocorreria quando categorizamos erroneamente tais noções.

Visto o que Ryle concebe por erro categorial, podemos dizer que, para o autor, grande parte dos problemas teóricos em filosofia da mente decorreriam da má categorização do conceito de mente. Assim, Descartes seria o grande sistematizador de tal concepção equivocada acerca da mente, justamente por arrolar numa mesma categoria as noções de mente e corpo. Mas o quê seriam mesmo as categorias? Voltemos por um momento a Aristóteles e investiguemos o conceito de categoria e verifiquemos se mentes e corpos poderiam ser coerentemente categorizados como sendo pertencentes à mesma categoria:

No primeiro livro de seus escritos lógicos intitulado justamente As Categorias (1967), Aristóteles, com efeito, discrimina dez tipos lógicos ou categorias dentro das quais situar-se-iam os conceitos. Tais categorias, a rigor, seriam: $1^{\circ}$ substância - (sendo os substantivos homem e cavalo exemplos de substância); $2^{\circ}$ quantidade - (um, uma dúzia); $3^{\text {o }}$ qualidade - (adjetivos do tipo branco, forte); $4^{\circ}$ relação - (maior, o dobro); $5^{\circ}$ lugar - (aqui, acolá); $6^{\circ}$ tempo - (antes, depois); $7^{\circ}$ situação ou postura - (sentado, deitado); $8^{\circ}$ possessão ou condição - (armado); $9^{\circ}$ ação - (cortar); $10^{\circ}$ paixão - (ser cortado).

Nesse contexto, podemos dizer que Ryle entende que o erro de Descartes foi o de

\footnotetext{
${ }^{66}$ "He was mistakenly allocating the university to the same category as that to which the other institutions belong".
} 
classificar a mente como pertencente à categoria de substância. Ou seja, assim como o estrangeiro da citação anterior esperava encontrar alguma entidade física à parte que designasse a universidade, não entendendo que a palavra universidade designava a maneira como todos os prédios e repartições que ele averiguou se relacionavam, analogamente, Descartes teria concebido a mente como uma substância (no sentido latino de res ou coisa). Em decorrência disso, todas as embaraçosas dicotomias concernentes às relações entre corpos e mentes viriam à tona, de modo que o problema da interação causal entre duas substâncias radicalmente distintas seria o mais evidente.

Em outras palavras, o termo mente não designaria uma substância material que víssemos andando por aí, muito menos uma substância imaterial capaz de animar corpos humanos como entendia Descartes por espírito. Pois, para Ryle, em contraste, mente não deveria ser entendida enquanto substância (seja ela material ou imaterial) como pensava Descartes, mas sim como o conjunto de propriedades disposicionais de comportamento.

Como exemplo de propriedade disposicional, poderíamos nos referir à fragilidade do vidro da seguinte maneira: caso atirássemos uma pedra numa janela de vidro, ela se partiria. Devemos deixar muito claro, porém, que tais propriedades disposicionais teriam múltiplas vias. Por exemplo: o vidro em questão só se partiria caso não fosse blindado. Para partir-se, a pedra em questão deveria ultrapassar um determinado limiar de tensão ou de resistência do vidro, etc. E mais: deve-se salientar que propriedades disposicionais não se restringiriam meramente ao plano físico-químico, de modo que, ainda de acordo com o exemplo do vidro, poderíamos atribuir juízos de caráter estético, dizendo que tal pedaço de vidro poderia ser considerado como belo ou feio, ou ainda, num plano social em particular, poderíamos associar a idéia de ousadia à quebra do vidro, caso se tratasse do vidro de uma delegacia, por exemplo. Enfim, seria muito difícil determinar um número preciso de 
propriedades disposicionais inerentes às coisas.

Quanto à atribuição de propriedades disposicionais às entidades inanimadas (como no exemplo acima citado) parece não haver grandes problemas. Porém, devemos atentar para a idéia de que ao atribuirmos propriedades disposicionais a sistemas que exibem comportamentos complexos (ou pelo menos mais complexos que vidros e pedras), tais como répteis e mamíferos, ou até mesmo a computadores, a situação parece se complicar. Isso porque, em geral, tais sistemas parecem exibir intencionalidade, ou melhor, tais sistemas parecem exibir propriedades mentais.

Neste último caso, ou seja, no que se refere a sistemas aos quais comumente atribuímos conteúdos mentais, as interpretações correntes acerca do pensamento de Ryle sugerem que o fato de tais sistemas exibirem propriedades disposicionais não implica que existam estados internos em tais sistemas, mas apenas que os sistemas em questão exibiriam um determinado comportamento frente a determinadas situações. Daí para a afirmação radical de que Ryle negaria a existência da mente é apenas um passo ${ }^{67}$.

Entretanto, essa não nos parece ser a real posição defendida por Ryle. Entendemos, em resumo, que Ryle em momento algum nega a existência de estados mentais, mas que sua preocupação consiste, antes, em negar, sim, um local privilegiado ou recipiente onde tais estados localizar-se-iam. E mais: estados mentais não teriam, para Ryle, nenhum poder causal em relação ao comportamento, no sentido cartesiano de précondição para a ação, segundo o qual todo sistema, antes de agir, representaria toda ação e

\footnotetext{
67 "Ryle sustenta, em contrapartida, que o fato de haver uma propriedade disposicional não implica que exista um estado interno do objeto, mas apenas que ele teria um determinado comportamento em determinadas condições" (Engel, P., s/d). Ou ainda: "De acordo com a análise behaviorista, por exemplo, minha crença de que está chovendo consiste em padrões de comportamento e disposições ao comportamento. Ter tal crença reside, por exemplo, no fato de que uso uma capa de chuva e carrego um guarda chuva quando saio. (E lembrem-se, esses comportamentos são apenas movimentos corporais. Não devemos considerá-los como tendo algum componente mental)". (Searle, 1998).
} 
ser efetuada.

A classificação de hipóteses complexas propostas por determinados autores, como nos parece ser o caso das idéias de Ryle, normalmente encerra mesmo certos mal entendidos. O principal deles, como vimos acima, seria o de que Ryle pura e simplesmente nega a existência da mente. Mas em nosso entender, a perspectiva adotada por Ryle não considera a mente enquanto coisa (res), localizada num local específico (encerrada nos limites de nossa caixa craniana). Assim, Ryle não negaria a existência da mente, mas apenas a conceberia de maneira distinta das concepções que a tomam por substância.

$\mathrm{Na}$ perspectiva ryleana, a mente seria concebida numa espécie de relação agente/mundo, ou seja, a mente se expressaria em termos de disposições (que podem ser atualizadas ou não) para o comportamento, ou melhor, para o fluxo de habilidades no plano da ação, não estando contida num recipiente de acesso privilegiado mediante introspecção. Assim, dizer que Ryle não concebe a existência de um estado interno no sistema (Engel) até que faria sentido, mas a partir disso inferir que Ryle nega a existência da mente (Searle) não procederia pelas razões que acabamos de ver.

No que tange às críticas dirigidas ao pensamento de Ryle (e, por extensão, ao behaviorismo lógico no qual comumente tentam enquadrar suas idéias), a principal delas seria a de que as tais propriedades disposicionais de múltiplas vias, quando referentes a estados mentais, seriam infinitas e passíveis de não mais poderem ser definidas em termos de comportamentos publicamente observáveis. Numa longa passagem, observa Churchland (2004):

A lista de condicionais necessárias para uma análise adequada de "quer férias no Caribe", por exemplo, parece ser não apenas longa, mas, sim, indefinidamente, ou mesmo infinitamente, longa, sem um modo finito de especificar os elementos 
que devem ser incluídos. E não é possível definir bem um termo cujo definiens é não específico e permanece em aberto dessa forma. Além disso, cada condicional da longa análise é por si só suspeito. Supondo que Anne efetivamente queira férias no Caribe, o condicional (1), anterior, será verdadeiro somente se ela não buscar fazer segredo sobre suas fantasias em termos de férias; o condicional (2) será verdadeiro somente se ela ainda não estiver entediada com os prospectos sobre a Jamaica; o condicional (3) será verdadeiro somente se ela não acreditar que o vôo de sexta-feira será seqüestrado, e assim por diante. Mas corrigir dessa forma cada condicional pelo acréscimo de uma qualificação apropriada seria reintroduzir uma série de elementos mentais na definição, e assim não estaríamos mais definindo o mental exclusivamente em termos de circunstâncias e comportamentos publicamente observáveis” (2004, p. 51).

Entretanto, entendemos que tal crítica não procederia porque para Ryle a mente expressa no comportamento mediante disposições, ou melhor, as disposições de comportamento emergente da relação agente/mundo não admitiriam recortes, ou seja, não poderiam ser tomadas como mera abstração, de modo que cada decisão tomada por um indivíduo (como no exemplo de Churchland) não deveria pressupor uma relação indefinida de disposições.

De outra maneira, pensamos que Ryle entende que expressas na própria história de cada indivíduo haveria condicionantes ou disposições (que não seriam ilimitadas) explícitas a todo bom observador, e que de uma certa maneira, pelo menos em alguns casos, serviria de elemento restritor para certas ações; o que invalidaria o argumento de que cada comportamento pressuporia um número infinito de disposições.

De modo menos abstrato, ao vermos um hipocondríaco desagasalhado caminhando numa fria manhã de segunda-feira, caso saibamos que tal indivíduo é um hipocondríaco, imediatamente descartamos a possibilidade de que ele se sente à vontade em tal situação; enfim, conhecendo um pouco de sua história, pensaremos que ele perdeu ou molhou seu casaco, dentre outras hipóteses similares, e, para não chegar atrasado ao trabalho, teve de se submeter à friagem matutina; ou seja, as possibilidades ou condicionantes são muitas, é 
verdade, mas não são infinitas.

Uma das lições a ser extraída das análises efetuadas por Ryle seria a de, que ao investigar a relação mente-corpo, não se precisa, necessariamente, fornecer definições específicas acerca da constituição última da matéria ou corpo, tampouco da mente; de modo que tal plano de análise contorna as objeções de Chomsky (2000) avaliadas no final do segundo capítulo.

Ademais, epistemologicamente, a acurada análise lógica do discurso e perspicaz investigação do comportamento permite que uma luz seja lançada sobre o problema dos qualia. Expliquemos.

No caso da dor, por exemplo, com um discurso afiado logicamente, bem como a acurada análise da história de um determinado indivíduo, é possível que se emita juízos pertinentes sobre o modo como esse indivíduo lida com um certo tipo de dor. Imaginemos um yogue experiente. É de se esperar que uma torção de tornozelo provoque um matiz de dor diferente da dor experimentada (tendo em vista uma mesma contusão) por um americano obeso e sedentário. Ou seja, a disciplina mental e física de um yogue, muito provavelmente, colaborará para que o teor de uma dor e seu controle, ou modo como este a expressa, sejam distintas do mesmo tipo de afecção que atinge um ocidental indisciplinado e afeito a analgésicos.

Enfim, tendo em vista a perspectiva que delineamos acima que ressalta uma acurada análise da história na qual todo sistema se encontra imerso, bem como a importância do uso de um instrumental teórico-conceitual bem articulado capaz de viabilizar que analogias ou comparações (como no exemplo do parágrafo precedente) possam ser efetuados, pensamos que o estudo das sensações pode ser ainda mais acurado com a aplicação de duas importantes noções, a saber: a de espaço informacional e duplo 
aspecto informacional, tal como Chalmers $(1996,1997)$ as concebe.

Tendo em vista nossa intenção de desenvolvermos futuramente em maiores detalhes a análise da experiência consciente numa perspectiva informacional, por hora, ou melhor, para encerrar o presente trabalho, apresentemos as linhas gerais da proposta de Chalmers.

Segundo Chalmers, grosso modo, um espaço informacional seria uma estrutura relacional que pauta a diferença entre determinados elementos, de modo a caracterizar diferenças e similaridades entre esses elementos. Ou ainda, um espaço informacional poderia ser tomado como um "objeto" abstrato no qual (na esteira de Shannon) a informação pode ser "vista" em sua realização física numa relação entre elementos físicos, de modo que as diferenças e similaridades entre dois ou mais elementos devem ser compreendidas mediante a análise de suas "trilhas" causais.

Já no que tange propriamente ao duplo aspecto da informação, Chalmers dirá que este se origina da suposição de que há um isomorfismo entre certos espaços organizacionais de informação realizados ou expressos fisicamente e certos espaços de informação fenomenológicos. Assim, a informação, para Chalmers, possuiria (pelo menos) dois tipos básicos, quais sejam, o fenomenológico e o físico.

Menos abstratamente, e, retomando nosso exemplo do yogue experiente e do americano obeso, podemos dizer que, na perspectiva rapidamente delineada acima, em se tratando de estruturas físicas organizadas sob certos aspectos distintamente (com um dos elementos sendo disciplinado, flexível, magro, etc. e o outro indisciplinado, obeso, etc.), bem como equivalentes ou similares sob certos aspectos (ambos pertencentes à espécie humana, dotados de dois membros inferiores, dois superiores, capazes de se expressarem lingüisticamente, etc.), é de se supor que suas experiências subjetivas sejam diferentes, 
sobretudo, levando-se em consideração suas diferenças, ou melhor, seus espaços informacionais físicos dessemelhantes.

Mas não é só isso. Entendemos que, a partir do texto de Chalmers, pode-se conceber que não apenas a contrapartida informacional do plano físico influencia na qualidade experimentada pela consciência, mas fundamentalmente (tomando uma expressão emprestada de Bateson [1986]) "toda diferença que fizer diferença". Seja num plano normativo qualquer, cultural, enfim, seja em todo plano significativo em que a diferença implique, de fato, numa afecção ao sistema.

Para encerrar, observa-se que Chalmers reconhece que sua hipótese do duplo aspecto da informação envolve um certo grau de especulação, e, uma de suas conseqüências (que o autor julga extremamente elegante filosoficamente) seria a de que essa hipótese informacional da consciência pode acarretar a idéia de que onde há espaço informacional em termos físicos, poderia haver um espaço fenomenológico correspondente. Porém o autor também admite que caso se queira evitar o pampsiquismo, poder-se-ia pensar em elementos restritores (constraints) que impossibilitem que a um termostato, por exemplo, se atribua experiência consciente.

Como indicamos, não pretendemos, por hora, aprofundar tal plano de análise; sendo nossa intenção, tão somente, a de indicar uma futura perspectiva de estudo, em especial, uma perspectiva sistêmica mais restritiva que a hipótese geral delineada por Chalmers, em que, por exemplo, somente sistemas aos quais comumente se atribui vida possam ser atribuídos experiência. 


\section{Considerações finais}

Como considerações finais, recapitulemos brevemente os tópicos abordados em nosso trabalho, para, em seguida, avaliarmos o alcance e limitações do que foi estudado.

No primeiro capítulo, nossa intenção foi a de, num primeiro momento, desenvolver uma detalhada caracterização da relação mente-corpo no contexto da filosofia cartesiana. Neste sentido, procuramos ir um pouco além do que geralmente se apresenta em manuais de filosofia da mente, na medida em que procuramos fornecer uma visão orgânica do pensamento de Descartes, em especial, de sua instigante metafísica e caracterização do lugar do humano na natureza.

Os elementos centrais desenvolvidos nas duas primeiras seções, em resumo, seriam o contexto ou caldo de cultura subjacente ao que Chomsky (2000) denomina de filosofia mecânica cartesiana, que, como aventamos, articula-se como um inquietante conflito entre o livre-arbítrio da res cogitans e o mecanicismo que rege o funcionamento do mundo físico. Na segunda seção em especial, procuramos levar ao paroxismo essa tensão mediante a análise das sensações em sua filosofia, algo que, como observado, encontra-se na "encruzilhada" da relação mente corpo, na medida em que sendo (as sensações) um dos modos de ser do pensamento, é também, em grande medida, indissociável das operações corporais.

Procuramos expor também uma formulação contemporânea da relação mente-corpo que tende a ressaltar os aspectos qualitativos da experiência. Neste sentido, vimos que a relação mente-corpo (entendida enquanto problema filosófico, sobretudo, após a publicação dos escritos de Descartes) comporta duas perspectivas de análise, que seriam: sua dimensão ontológica e epistemológica. 
Como há de se ter percebido, enfatizamos em nossa exposição a dimensão epistemológica do problema; isso porque, no fundo (e como a última seção do capítulo final dá a entender), nossa preocupação fundamental foi a de lançar uma luz sobre a relação entre os discursos de primeira e terceira pessoas, no intuito de "encurtar" o abismo que aparentemente existe entre tais planos discursivos.

No segundo capítulo, procuramos expor, inicialmente, duas perspectivas materialistas de análise da relação mente-corpo, quais sejam, a teoria da identidade mentecérebro proposta por Smart (1970) e o materialismo eliminativista tal como P. M. Churchland (2004) o concebe. Em seguida, apresentamos algumas críticas dirigidas a tais perspectivas, bem como réplicas em defesa das teorias abordadas. Ao final da segunda seção do mesmo capítulo, apresentamos uma crítica geral dirigida ao materialismo em filosofia da mente, que consiste, basicamente, em pôr em evidência os problemas de se arrogar como materialista, tendo em vista que a própria noção de matéria constitui-se numa questão em aberto.

No terceiro capítulo, finalmente, após sinalizarmos que a teoria da identidade mente-cérebro comporta a possibilidade de que os estados mentais possam ser caracterizados em termos mais abrangentes, podendo ser atribuídos, sem nenhum empecilho lógico, a organizações cerebrais distintas, avaliamos o modo como Shoemaker (1980) entende ser possível definir funcionalmente um estado qualitativo.

No entanto, como pudemos observar, mesmo que se defina numa tabela os matizes de um determinado estado qualitativo, o problema da experiência consciente tende a permanecer tendo em vista sua própria formulação. Isso porque o problema de "ser ou sentir como outro ser experimenta o mundo" demanda, no fundo, uma espécie de acesso intersubjetivo direto, sendo que o termo "direto" deve ser tomado em sentido extremamente 
forte. Mas como no momento não se dispõe de meios para tanto, ou seja, para que se possa efetivar tal ligação intersubjetiva direta, argumentamos que, para não permanecermos num desestimulante ceticismo, uma maneira de abordar a questão consiste em promover uma acurada análise do comportamento expresso na história vivida de cada indivíduo e da linguagem.

Neste sentido, mediante o resgate dos estudos de Ryle, destacamos como a relação mente-corpo e a questão epistemológica da experiência consciente podem ser mais bem compreendidas tendo em vista uma perspectiva que denominamos de relacional, em que a mente é concebida não mais como coisa (res), localizada num recipiente e de acesso privilegiado, mas como uma propriedade disposicional, de múltiplas vias, expressa no comportamento e na história vivida de cada sistema.

Ao final do trabalho, traçamos uma breve possibilidade de análise futura mediante a apresentação das linhas gerais da abordagem informacional proposta por Chalmers (1996, 1997). De acordo com esta abordagem, em resumo, a experiência consciente seria investigada a partir da noção de espaço informacional, caracterizado como uma espécie de estrutura relacional que permite classificar diferenças e similitudes entre dois ou mais elementos. Assim, pressupondo sua teoria do duplo aspecto da informação (calcada na idéia de que existe um isomorfismo entre espaços informacionais expressos fisicamente e espaços de informação fenomenológicos), Chalmers dirá que a experiência pode ser caracterizada, grosso modo, mediante o entendimento das relações de similaridades e diferenças entre os espaços informacionais físicos e fenomenológicos, ressaltando a ênfase nas diferenças que fazem diferença para o percebedor.

Dado o que foi discutido no presente trabalho, façamos, finalmente, um breve balanço do que pensamos ser seus pontos positivos e também negativos. 
Em primeiro lugar, julgamos ser positiva a apresentação um tanto detalhada de certos tópicos concernentes à metafísica cartesiana. Isso porque, pensamos, certos lugares comuns tais como o rótulo de "dualista substancial", dentre outros comumente atribuídos a Descartes, podem ser questionados e até mesmo recolocados numa perspectiva mais crítica.

Um ponto do trabalho que talvez devesse ser desenvolvido consiste num posicionamento mais incisivo com relação às críticas e réplicas dirigidas às vertentes materialistas investigadas, particularmente, no que diz respeito às objeções levantadas por Chomsky em relação aos "problemas" em se arrogar, nos dias de hoje, materialista.

Dizemos que a ausência de um posicionamento mais incisivo com relação às idéias de Chomsky pode ser tomada como uma limitação do presente trabalho, em virtude do caráter discutível de seu argumento; pois na comunidade dos físicos, o desconhecimento das propriedades últimas da matéria e da energia escura não se afigura como um grande problema, na medida em que, mesmo desconhecendo as propriedades fundamentais da matéria, estimativas, mensurações e previsões de fenômenos são normalmente efetuados. Ademais, grande parte dos físicos parece entender que, podendo ser mensurada a quantidade de matéria e energia escura no universo, a descoberta de suas propriedades fundamentais. seria, então, apenas uma questão de tempo.

Um outro tópico do presente trabalho que poderia ser visto como uma limitação seria o não aprofundamento de importantes discussões abertas, tais como as concernentes ao estatuto da psicologia popular enquanto fonte de conhecimento, por exemplo.

Mas enfim, se algumas questões não puderam ser aprofundadas no presente trabalho, que mereceria, por exemplo, um quarto capítulo a respeito da perspectiva informacional da consciência proposta por Chalmers, ao menos, pensamos, as questões referentes à relação mente-corpo foram colocadas; o que por si só, pelo menos na filosofia 
da mente, pode ser considerado como algo positivo.

Por último, devemos destacar que o que pensamos ser o grande mérito do presente trabalho é o delineamento fornecido das bases de uma concepção mais ampla e não convencional da mente; que seria a perspectiva relacional/informacional dos estados mentais. Julgamos que tal abordagem se afigura como um ponto positivo, em virtude deste frutífero campo ainda ser pouco explorado em estudos de filosofia da mente. Além disso, tal perspectiva relacional/informacional da mente nos parece ser um ramo de estudo extremamente fértil no que tange ao desenvolvimento da especulação filosófica e confecção de novos conceitos. 


\section{Referências}

ARISTÓTELES. Categorias. In: . Obras. Tradução Francisco de P. Samaranch.

Madrid: Aguillar Ediciones, 1967. p. 232-253.

ARISTÓTELES. Del alma. In: . Obras. Tradução de Francisco de P. Samaranch. Madrid: Aguillar Ediciones, 1967. p. 824-872.

AUSTIN, J. L. Outras mentes. Tradução de Marcelo Guimarães da Silva Lima. São Paulo: Abril Cultural, 1975. p. 91-119. (Os Pensadores).

BLOCK, N. On a confusion about a function of consciousness. In: NED BLOCK, Owen Flanagan; GÜVEN, Güzeldere. (Orgs.). The nature of consciousness: philosophical debates. Cambridge, Massachusets: MIT Press, 1999. p. 375-419.

. Consciousness. In: GUTTENPLAN, S. (Org.) A companion to the philosophy of mind. Oxford: Blackwell Publishers, 1994. p. 210-219.

What is functionalism? In: . (Org.). Readings in philosophy of psychology. Cambridge: Harvard University Press, 1980. p. 171-184.

; FODOR, J. A. What psychological states are not. In: BLOCK, N. (Org.). Readings in philosophy of psychology. Cambridge: Harvard University Press, 1980. v. 1. p. 237-250.

BROENS, M. C. Algumas considerações sobre o conceito cartesiano de memória: um convite ao estudo interdisciplinar nas Ciências Cognitivas. In: GONZALEZ, M. E. Q.; DEL-MASSO, M. C. S.; PIQUEIRA, J. R. C. (Orgs.). Encontro com as ciências cognitivas. São Paulo: Cultura Acadêmica, 2001. p. 27-34. V. 3.

CARAVEO, P; RONCADELLI, M. O enigma da matéria escura. Scientific American Brasil, São Paulo: Segmento; Ediouro, n.3, p. 26-33, ago, 2002.

CHALMERS, D. J. Facing up to the problem of consciousness. In: SHEAR, J. (Ed.) Explaining consciousness - the 'hard problem'. Cambridge MA: The MIT Press, 1997. 
CHALMERS, D. J. The conscious mind. New York: Oxford University Press, 1996. 404p.

CHURCHLAND, P..M. Matéria e consciência: uma introdução contemporânea à filosofia da mente. Tradução Maria Clara Cescato. São Paulo: Ed. UNESP, 2004. 286 p.

CHOMSKY, N. New horizons in the study of language and mind. Cambridge: University Press, 2000. p. 75-133.

COTTINGHAM, J. Dicionário Descartes. Tradução Helena Martins. Rio de Janeiro: Zahar, 1995. p. 76-79.

DAVIDSON, D. Mental events. In: ROSENTHAL, D. (Ed.) The nature of mind. New York: Oxford University Press, 1991, p. 247-256.

DESCARTES, R. Cartas. In: . Obra escolhida. Tradução J. Guinsburg e Bento Prado Júnior. Rio de Janeiro: Bertrand Brasil, 1994. p. 413-416.

Discurso do método. In: . Discurso do método, Meditações. Objeções e respostas. As paixões da alma. Cartas. Tradução de J. Guinsburg e Bento Prado Júnior. São Paulo: Abril Cultural, 1973. p. 33-79. (Os Pensadores).

Meditações. In: . Discurso do método. Meditações. Objeções e respostas. As paixões da alma. Cartas. Tradução de J. Guinsburg e Bento Prado Júnior. São Paulo: Abril Cultural, 1973. p. 91-150. (Os Pensadores).

As paixões da alma. In: . Discurso do método. Meditações. Objeções e respostas. As paixões da alma. Cartas. Tradução J. Guinsburg e Bento Prado Júnior. São Paulo: Abril Cultural, 1973. p. 223-304. (Os Pensadores).

ENGEL, P. Introdução à filosofia do espírito. Tradução José Pedro Cabrera. Lisboa: Instituto Piaget, [199-] 251p.

FODOR, J. A. The language of thought. Cambridge: Harvard University Press, 1975. 
FREGE, G. Lógica e filosofia da linguagem. Tradução Paulo Alcoforado. São Paulo: Cultrix, 1978, cap. 2.

FREUD, S. Projeto de uma psicologia. In: . Obras Isoladas. Tradução Osmyr Faria

Gabbi Júnior. Rio de Janeiro: Imago, 1995.

GALDÓS, B. P. Nazarin. Madrid: Aguillar Ediciones, 1960. 74 p.

GONZALEZ, M. E. Q. Um estudo cognitivo-informacional das representações mentais. In: ABRANTES, P. (Org.). Epistemologia e cognição. Brasília: Ed. UNB, 1994. p. 127-146.

HASELAGER, W. F. G. O mal estar do representacionismo: sete dores de cabeça da Ciência Cognitiva. Tradução Mariana Cláudia Broens. In: FERREIRA, A.; GONZALEZ, M. E. Q., COELHO, J. G. (Orgs.). Encontro com as ciências cognitivas. São Paulo: Cultura Acadêmica, 2005. v. 4. p. 105-120.

HUXLEY, A. As portas da percepção. Tradução de Osvaldo de Araújo Souza. Rio de Janeiro: Civilização Brasileira, 1973. 50 p.

JACKSON, F. What Mary didn’t know. Journal of philosophy. v. 83, p. 291-295, 1986.

KORNBLITH, H. Naturalismo: metafísico e epistemológico. In: ÉVORA, Fátima R.; ABRANTES, Paulo (Orgs.). Cadernos de história e filosofia da ciência. Tradução Dani Leonor e Paulo Abrantes. Campinas: revista semestral do centro de lógica, epistemologia e história da ciência, 1998. p. 147-169.

KOYRÉ, A. Do mundo fechado ao universo infinito. Tradução Donaldson M. Garschagen. Rio de Janeiro: Forense Universitária; São Paulo: EDUSP, 1979. p. 90-109.

LEIBINIZ, G. Novos ensaios sobre o entendimento humano. Tradução Luiz João Baraúna. São Paulo: Nova Cultural, 1996. p. 211-226. (Os Pensadores).

LEVINE, J. Materialism and qualia: the explanatory gap. Pacific Philosophical Quarterly, v. 64. p. 354-361, 1983.

MANN, T. A montanha mágica. Tradução Herbert Caro. Rio de Janeiro: Nova Fronteira, 
1980. 801 p.

MARGOTTA, R. História ilustrada da medicina. São Paulo: Manole, 1998.

MILIDONI, C. B. Metapsicologia freudiana e ciência cognitiva: os riscos da interdisciplinaridade. In: GONZALEZ, M. E. Q.; DEL-MASSO, M. C. S.; PIQUEIRA, J. R. C. (Orgs). Encontro com as ciências cognitivas. São Paulo: Cultura Acadêmica, 2001. p. 3-11.

NAGEL, E. Issues in the logic of reductive explanations. In: Teleology revisited and other essays in the philosophy of science. New York: Columbia University Press, 1979. p. 95117.

NAGEL, T. What is it like to be a bat? ? In: BLOCK, N. (Org.). Readings in philosophy of psychology. Cambridge: Harvard University Press, 1980. p. 159-168. V. 1

PLACE, U. T. Is consciousness a brain process? In: BORST (Org.). A mind/brain identity theory. London: The Macmillan Press, 1970. p. 42-51.

PLATÃo. A república. Tradução Maria Helena da Rocha Pereira. Lisboa: Fundação Calouste Gulberkian, 1983.

PUTNAM, H. The meaning of 'meaning'. In: Mind, language and reality. philosophical papers, Cambridge: Cambridge University Press, 1975. p. 215-271.

PUTNAM, H. The nature of mental states. In: BLOCK, N. (Org.). Readings in philosophy of psychology. Cambridge: Harvard University Press, 1980. p. 223-231. V.1

RYLE, G. The concept of mind. Londres: Penguin Books, 2000.

SEARLE, J. R. A redescoberta da mente. Tradução Eduardo Pereira e Ferreira. São Paulo: Martins Fontes, 1997. 379 p.

SEARLE, J. R. O mistério da consciência. Tradução André Yuji Pinheiro Uema e Vladimir Safatle. São Paulo: Paz e Terra, 1998. 239 p. 
SEARLE, J. R. Mente, cérebro e ciência. Tradução Artur Morão. Lisboa: Edições 70, [1997]. cap.1.

SELLARS, W. Empiricism and philosophy of mind. Science, perception and reality. London: 1963.

SHOEMAKER, S. Functionalism and qualia. In: BLOCK, N. (Org.). Readings in philosophy of psychology. Cambridge: Harvard University Press, 1980. p. 251-267. V. 1.

SMART, J. J. C. Sensations and brain processes. In: BORST (Org.). The mind Brain/identity theory. London: The Macmillan Press, 1970a. p. 52-66.

SOARES, A. O que são ciências cognitivas. São Paulo: Brasiliense, 1993.70 p. (Primeiros Passos). 70 p.

STALNAKER, R. Propositional attitudes. In: ROBERT A. W.; FRANK C. K. (Orgs.). The MIT Encyclopedia of Cognitive Sciences. Cambridge, Massachusetts, 1999. p. 678-679.

VICENTINI, M. R. Como percebemos o mundo que nos cerca? Bauru: EDUSC, 1999. 104 p.

WITTGENSTEIN, L. Investigações filosóficas. Tradução Marcos G. Montagnoli. Petrópolis: Vozes, 1996. 350 p. 